\title{
Ortefato impresso na Época Moderna: forma e materialidade dos produtos da prensa manual preservados no acervo de obras raras da Biblioteca Central da Universidade de Brasília
}

Early Modern Printed Artefacts: Form and materiality of hand-press works housed at the rare book collection of the University of Brasilia's Central Library

https://doi.org/10.1590/1982-02672021v29e19

\author{
ANDRÉ DE MELO ARAÚJO' \\ https://orcid.org/0000-0002-8483-8235 \\ Universidade de Brasília / Brasília, DF, Brasil
}

RESUMO: Neste artigo, articulam-se simultaneamente dois eixos investigativos com o propósito de apresentar o ganho analítico que o estudo da materialidade de impressos da Época Moderna, de sua produção gráfica coletiva e de seus processos de edição, bem como dos modos de organização textual e visual da informação registrada em papel ao longo do tempo trazem para a pesquisa histórica. Em um primeiro eixo, tem-se por objetivo familiarizar leitores e leitoras com aspectos mais gerais relacionados à produção de impressos no período. Uma vez que os produtos da prensa manual frequentemente apresentam uma configuração e exibem marcas particulares originadas em momentos distintos, o segundo eixo investigativo deste artigo dedica-se à análise gráfica e material de exemplares paradigmáticos, majoritariamente pertencentes à coleção de obras raras da Biblioteca Central da Universidade de Brasília e impressos no continente europeu entre os séculos XVI e XVII. Ao analisá-los, defende-se a tese segundo a qual os artefatos impressos na Época Moderna refletem padrões culturais, ao mesmo tempo que resultam de limites impostos pela técnica e por decisões de ordem econômica.

\begin{abstract}
1. Professor de História Moderna na Universidade de Brasília. Bolsista de Produtividade do Conselho Nacional de Desenvolvimento Científico e Tecnológico (CNPq). Pelas conversas inspiradoras e pela leitura atenta do manuscrito, agradeço a Alícia Duhá Lose, Leandro Rust, Luiz César de Sá, Marina Bezzi, Marina Garone Gravier, Raphael Greenhalgh, Valeria Gauz e aos/às pareceristas anônimos/as deste artigo. E-mail: $<$ andre_meloaraujo@yahoo. com.br>.
\end{abstract}


PALAVRAS-CHAVE: História do livro. Época Moderna. Cultura material. Bibliografia material. Acervos de obras raras. Biblioteca Central da Universidade de Brasília.

ABSTRACT: In this article, I argue that early modern printed artifacts reflect cultural patterns, whilst being a result of the limits imposed by economic decisions and technique. By articulating two investigative scales, I highlight the analytical gain that the study of the materiality of early modern printed artefacts and their collective graphic production and editing processes, as well as of the modes of textual organization and visual information recorded on paper over time provide to historical research. On the one hand, the article introduces readers to the general aspects of production of printed material in the period. On the other hand, since hand press' printed artefacts often exhibit specific configurations and marks originated at different periods of time, the article examines the graphic and material features of paradigmatic examples printed in the European continent, in the 16th and 17th centuries. Most of the analysed materials are housed at the rare book collection of the University of Brasilia's Central Library.

KEYWORDS: History of the book. Early Modern History. Material culture. Material bibliography. Rare book collections. University of Brasília's Central Library. 
A obra impressa mais antiga pertencente ao acervo de obras raras da Biblioteca Central da Universidade de Brasília passou despercebida por décadas. Sua catalogação, confiante nas informações registradas na primeira página impressa, levou a que os processos editoriais que the deram origem e as alterações gráficas feitas na peça permanecessem desconhecidos. À primeira vista, a folha de rosto de uma coleção renascentista de tratados médicos associados ao nome de Hipócrates não apresentava motivos para levantar desconfiança. Em papel avergoado quinhentista, registra-se a data de 1538, sendo esta a informação inicialmente inserida no catálogo da universidade. Todavia, no colofão - ou seja, no bloco de texto informativo relativo à produção do livro e inserido ao final dos cadernos principais - anuncia-se que as páginas da obra foram levadas à prensa no ano de 1526 (cf. Figura 1), fazendo dela edição mais antiga que as cartas de Plínio, o Jovem, publicadas em 1533 e também sob a guarda da biblioteca brasiliense. Mas como explicar a contradição entre as datas apresentadas na primeira e na última página de um mesmo título? Que relações se pode estabelecer entre as informações registradas em papel e a história de produção, circulação e preservação de um artefato impresso na Época Moderna?
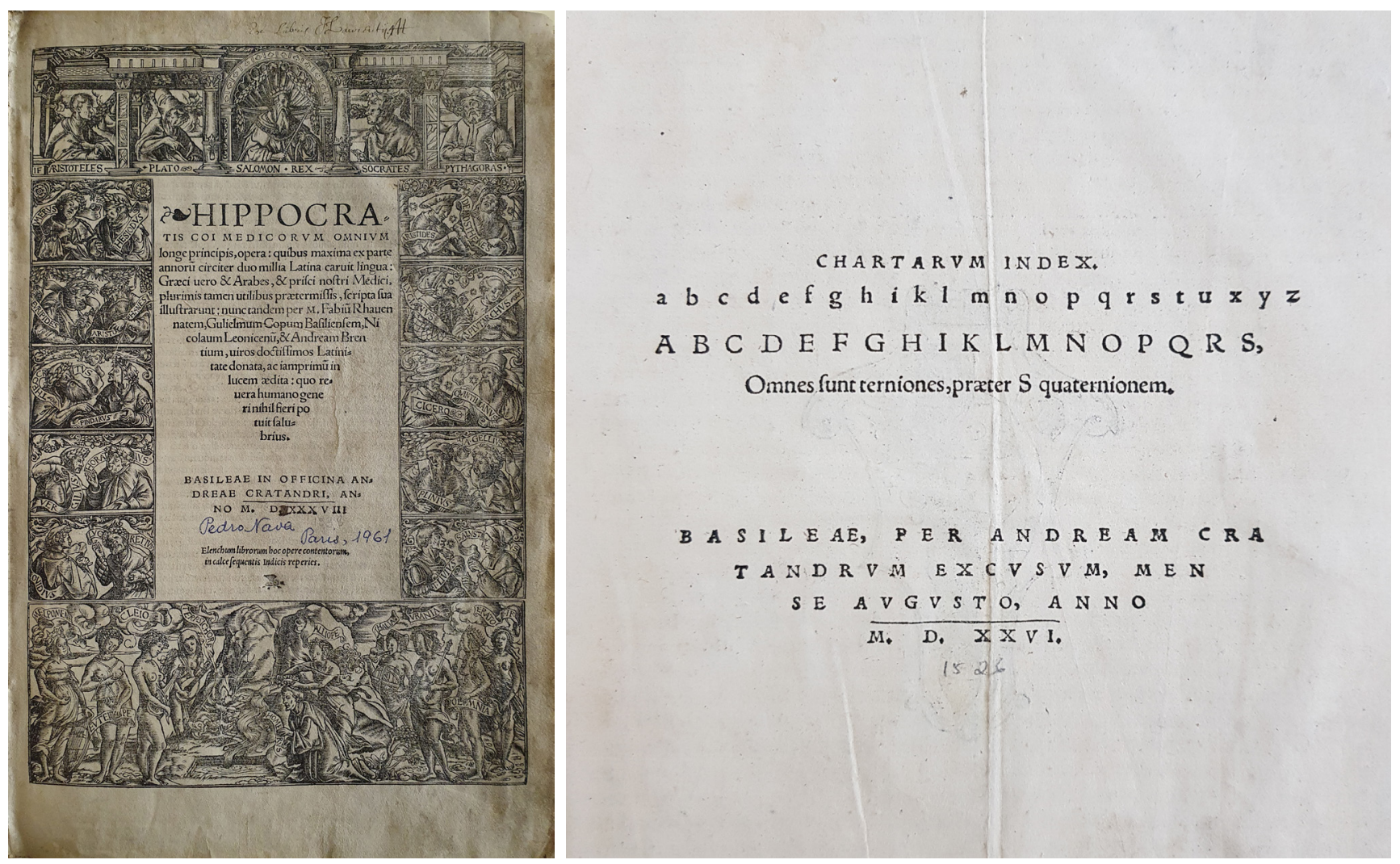

Figura 1 - Folha de rosto e colofão da obra Hippocratis coi medicorvm omnivm (1526). Acervo da Biblioteca Central da Universidade de Brasília. 
2. Os erros da tradução de Calvo, seu impacto na recepção do Corpus Hippocraticum - inclusive no que diz respeito à segunda edição feita na Basileia por Cratander - e o caso da correspondência datada de 1527 e dirigida a Erasmo sobre o tema foram recentemente estudados por Mathias Witt (2018, p. 73).

3. Para a história textual do Corpus Hippocraticum, considerando-se as edições gregas aldina (1526) e aquela de Janus Cornarius (1538), cf. Jouanna (2018).
Para os estudos da história do livro, o caso do exemplar brasiliense é eloquente, a começar pela importância que os anos de 1526 e 1538 têm para o estabelecimento e a difusão do Corpus Hippocraticum, larga e crescentemente valorizado pela cultura médica ao longo do século XVI. Suas primeiras edições impressas foram a tradução latina, preparada por Marco Fabio Calvo e datada de 1525, a que se sucede a edição grega, por sua vez levada à prensa no ano seguinte na oficina da família Manúcio em Veneza e que consiste na edição princeps do texto grego.

Já a publicação produzida na Basileia por Andreas Cratander - sendo estes o local e o impressor apresentados tanto na folha de rosto quanto no colofão do exemplar da Universidade de Brasília - data igualmente de 1526 e tem por base o texto latino estabelecido por Calvo, como informado na advertência ao leitor. Ocorre que os erros introduzidos por Calvo no texto latino foram parcialmente reproduzidos na edição de Cratander e passaram a ser comentados, imediatamente, por integrantes de círculos letrados renascentistas. ${ }^{2}$ Para combater os desvios do texto grego levado à prensa, o humanista Janus Cornarius preparou uma edição revisada da edição princeps Aldina, agora impressa na oficina da família Froben na Basileia em 1538,3 em direta concorrência ora com a própria edição veneziana, ora com os produtos disponibilizados no mercado local pela prensa de Cratander. $\bigcirc$ ano de 1538, portanto, é fundamental para a difusão humanística do Corpus Hippocraticum, motivo pelo qual se poderia inicialmente suspeitar da elaboração tardia de uma nova folha de rosto preparada para atualizar a edição latina de 1526 e disputar espaço com o título mais recente saído da oficina de Froben. Todavia, o papel utilizado para a impressão da folha de rosto que figura no exemplar brasiliense exibe marca d'água compatível com aquela presente em algumas páginas internas da obra. E como dificilmente um impressor do período teria guardado parte do dispendioso estoque de papel utilizado por Cratander para imprimir sua edição do Corpus Hippocraticum com o objetivo de levar uma nova folha de rosto à prensa doze anos mais tarde, resta-nos investigar a possibilidade de produção simultânea das peças e apostar no ganho analítico que o estudo gráfico e material de artefatos impressos no período revela para a pesquisa histórica.

As obras produzidas à época da prensa manual estavam sujeitas a erros e manipulações reveladoras. Mesmo as edições mais bem cuidadas, como aquelas valorizadas pela tradição humanística renascentista e impressas em grande formato, encontravam-se entregues às variações características de produtos manufaturados. Assim, as mãos do compositor responsável por dispor os tipos móveis nas fôrmas da oficina de Cratander enganaram-se ao organizar - sequenciamento numérico das páginas da edição latina dos tratados hipocráticos impressa, segundo o colofão, em 1526. Os exemplares saídos neste ano da prensa da Basileia exibem o número 219 no canto superior direito da 
página 223, exatamente como no caso da numeração identificada na cópia preservada na Universidade de Brasília (cf. Figura 19). A uniformidade do erro manual em diversos exemplares passa a ser indício histórico de autenticidade documental. Até aqui, sabe-se, portanto, que ao menos as páginas internas da obra correspondem, de fato, à edição impressa em 1526.

Ocorre que a prensa manual não era apenas (re)produtora de erros, mas também de padrões. Assim, o refinamento gráfico da folha de rosto com cercadura em relevo da edição de Cratander não era exclusividade da tradição textual hipocrática. As quatro peças que integram a imagem e apresentam o título da obra cercada pela coroação de Homero - por sua vez ladeado pelas figuras de Aristóteles, Platão, Píndaro, Ovídio, Pitágoras e Eurípedes - foram utilizadas na Geografia de Estrabão, publicada três anos antes. ${ }^{4} \bigcirc$ livro foi impresso por Valentino Curio, que aprendera a arte da impressão com Cratander e abrira sua própria oficina em 1522. A tensão entre Curio e Cratander havia se intensificado por conta da publicação, por ambas as prensas, de um dicionário da língua grega, originalmente editado em Milão, posteriormente em Veneza e mais recentemente expandido pelas penas humanistas da Basileia. ${ }^{5}$ De fato, as décadas de 1520 e 1530 foram de fundamental importância para a criação de um mercado de livros europeu que se beneficiou sobretudo da expansão das atividades da prensa nas cidades de Lyon, Paris, Amsterdã e da Basileia. ${ }^{6}$ Consequentemente, acirra-se a competição entre impressores, livreiros e editores que, para contornar os riscos comerciais envolvidos na produção dispendiosa de impressos, frequentemente associavam-se na manufatura de uma série de títulos. Assim, Cratander tanto publicou textos de Erasmo com consentimento do respeitado impressor Johann Froben 7 quanto levou à prensa obras realizadas em parceria com um jovem aprendiz de Froben, Johann Bebel. ${ }^{8}$ Nesse cenário simultaneamente concorrencial e associativo, o artista Hans Holbein, o Jovem, atendia às demandas editoriais de Cratander, Curio, Froben e Bebel. A partir do verão de 1522, seus desenhos serviram de base para gravuras em relevo, frequentemente transpostas para o metal por Jakob Faber, estampadas nas oficinas dos quatro impressores. 9 Esse é o caso da cercadura em relevo que figura no Corpus Hippocraticum editado por Cratander e identificada pelo monograma IF Uakob Faber) no canto superior esquerdo da imagem. Além de já ter passado pela prensa de Curio, a mesma cercadura ainda se encontra presente na folha de rosto de outro título em latim impresso no mesmo ano e igualmente na Basileia por Johann Bebel. A matriz metálica se deslocou, portanto, de uma oficina de impressão para outra, como se verifica nas obras reproduzidas na Figura 2.
4. Cf. Schmid (1899, p. 251); Siraisi (2007, p. 82-84).

5. Sobre as disputas comerciais entre Curio e Cratander, cf. Winger (1983, p. 180-181).

6. Cf. Pettegree (2010, p. $65-$ 90).

7. Sebastiani (2018, p. 68).

8. Bietenholz (1985, p. 357).

9. Dodgson (1943); Schmid (1899, p. 239-242). 
10. Fuchs; Palmer (2020, p. 1242).
Ocorre que essa história tem um capítulo anterior. A cercadura em relevo gravada por Jakob Faber reconfigura uma imagem já impressa em diversas ocasiões na Basileia e igualmente atribuída a Holbein. Nela, figuram autores clássicos gregos e latinos que apresentam as obras de Erasmo publicadas entre fevereiro de 1515 e janeiro de 1523 por Johann Froben (cf. Figura 3).

De fato, não era incomum que gravuras - e até mesmo tipos móveis passassem pelas mãos de distintos impressores na época da prensa manual. A edição alemã da Utopia de Thomas Morus publicada em 1524 por Bebel adota os mesmos tipos utilizados por Froben para imprimir o alfabeto 'utópico' na edição latina de $1518 .{ }^{10}$ Consequentemente, tem-se que as estreitas conexões estabelecidas entre as oficinas de impressão na Basileia quinhentista resultaram em padrões recorrentes. Assim, ao se comparar o padrão gráfico de obras impressas na Basileia ao longo da década de 1520, percebem-se regularidades não apenas nos tipos móveis e nos ornamentos aplicados às folhas de rosto, mas também no modo de organização tipográfica da informação. Note-se inicialmente que a follha de rosto produzida na oficina de Curio e o colofão de 1526 da obra de Cratander obedecem a um mesmo padrão tipográfico de registro das datas com algarismos romanos. Nas duas peças, o compositor separou claramente as representações do milhar e da centena, o que também ocorre no caso da centena e das dezenas com as unidades. Seria esperado, portanto, que o compositor mantivesse padrão semelhante de espaçamento na folha de rosto do Corpus Hippocraticum. A comparação com diversos outros exemplares do mesmo título, a exemplo daquele preservado na Universidade de Michigan, revela que esse padrão de espaçamento é respeitado. Alinhando-se as letras impressas nas folhas de rosto dos exemplares estadunidense e brasiliense, vê-se claramente que os algarismos romanos adicionais necessários para alterar a data de 1526 para 1538 - nesse caso, uma letra X e duas letras I - ocupam exatamente a região destinada aos espaços em branco, de acordo padrão seguido pelos compositores da Basileia (cf. Figura 4). 

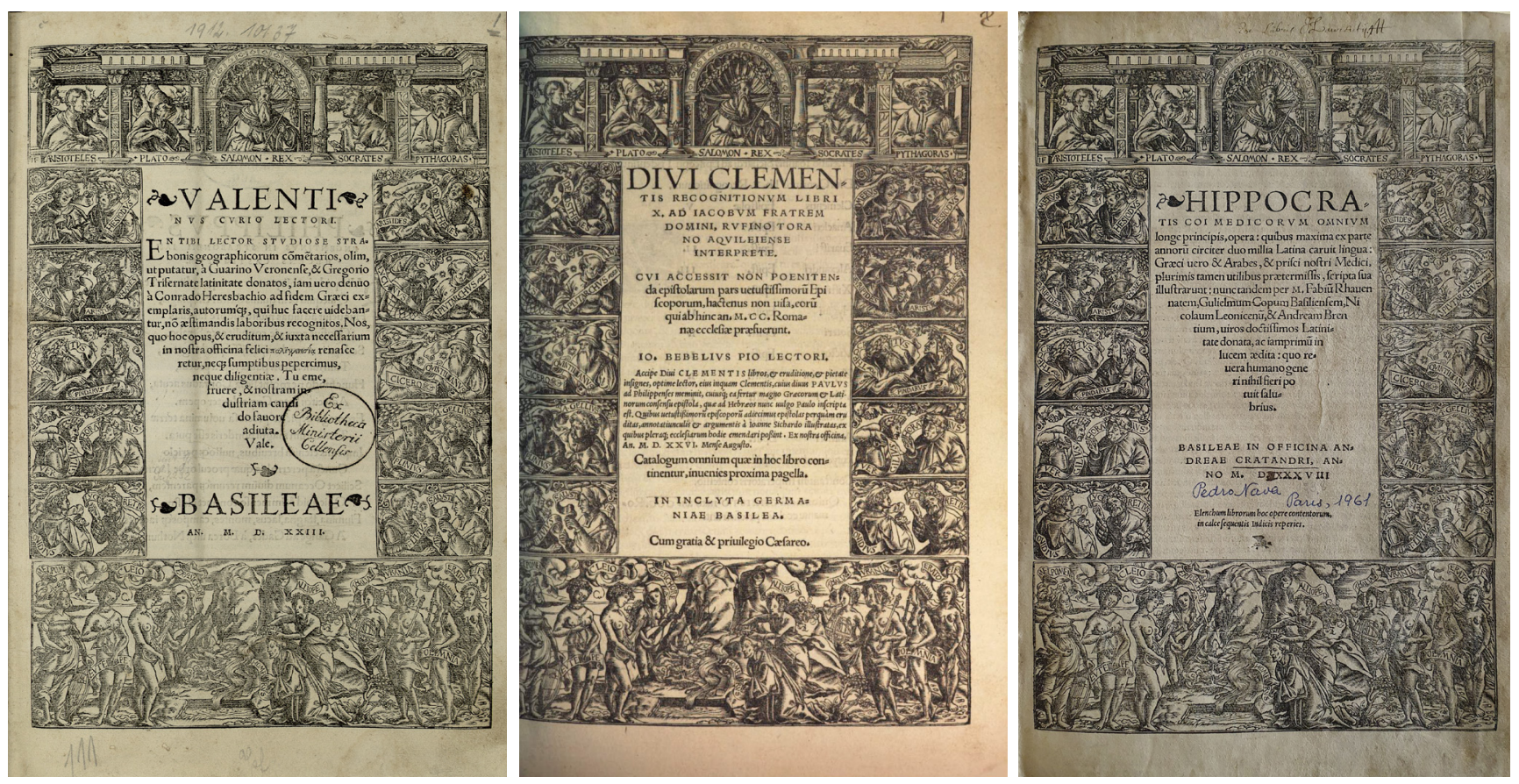

Figura 2 - Folhas de rosto das obras: Valentinvs cvrio lectori (1523) (esq.), Divi Clementis Recognitionvm Libri X (1526) (centro) e Hippocratis coi medicorvm omnivm (1526) (dir.). Acervos da Niedersächsische Staats- und Universitätsbibliothek Göttingen [n. cat.: 4 AUCT GR IV, 7082 (1)], Bayerische Staatsbibliothek, Munique e Biblioteca Central da Universidade de Brasília, respectivamente.
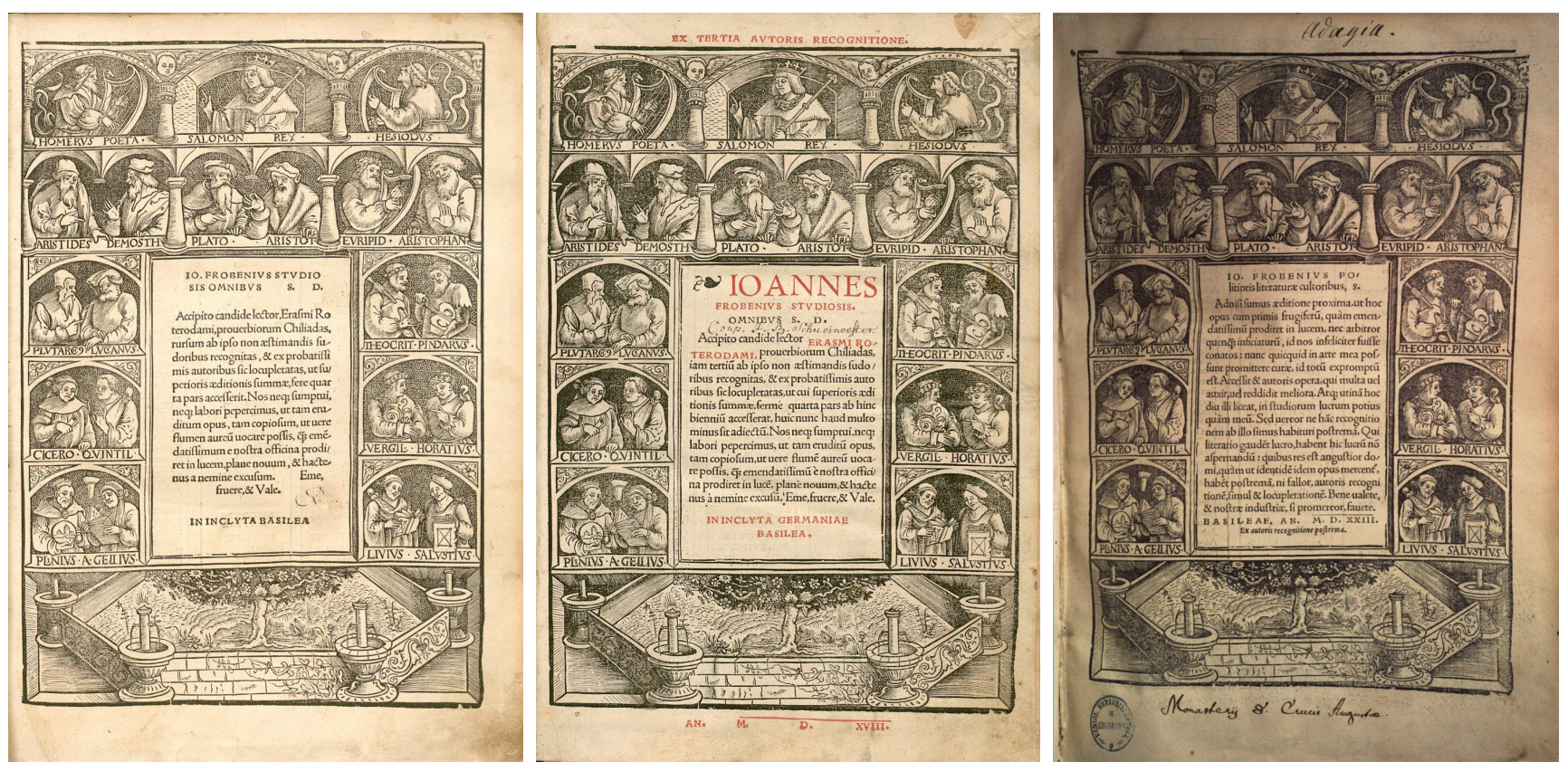

Figura 3 - Folhas de rosto das obras de Erasmo: lo. Frobenivs Stvdiosis Omnibvs... (1515) (esq.), Proverbia (1518) (centro) e lo. Frobenivs Politioris literaturae cultoribus... (1523) (dir.). Acervo da Bayerische Staatsbibliothek, Munique. 
11. Galeni Pergameni Svummi Semper Viri (1538).

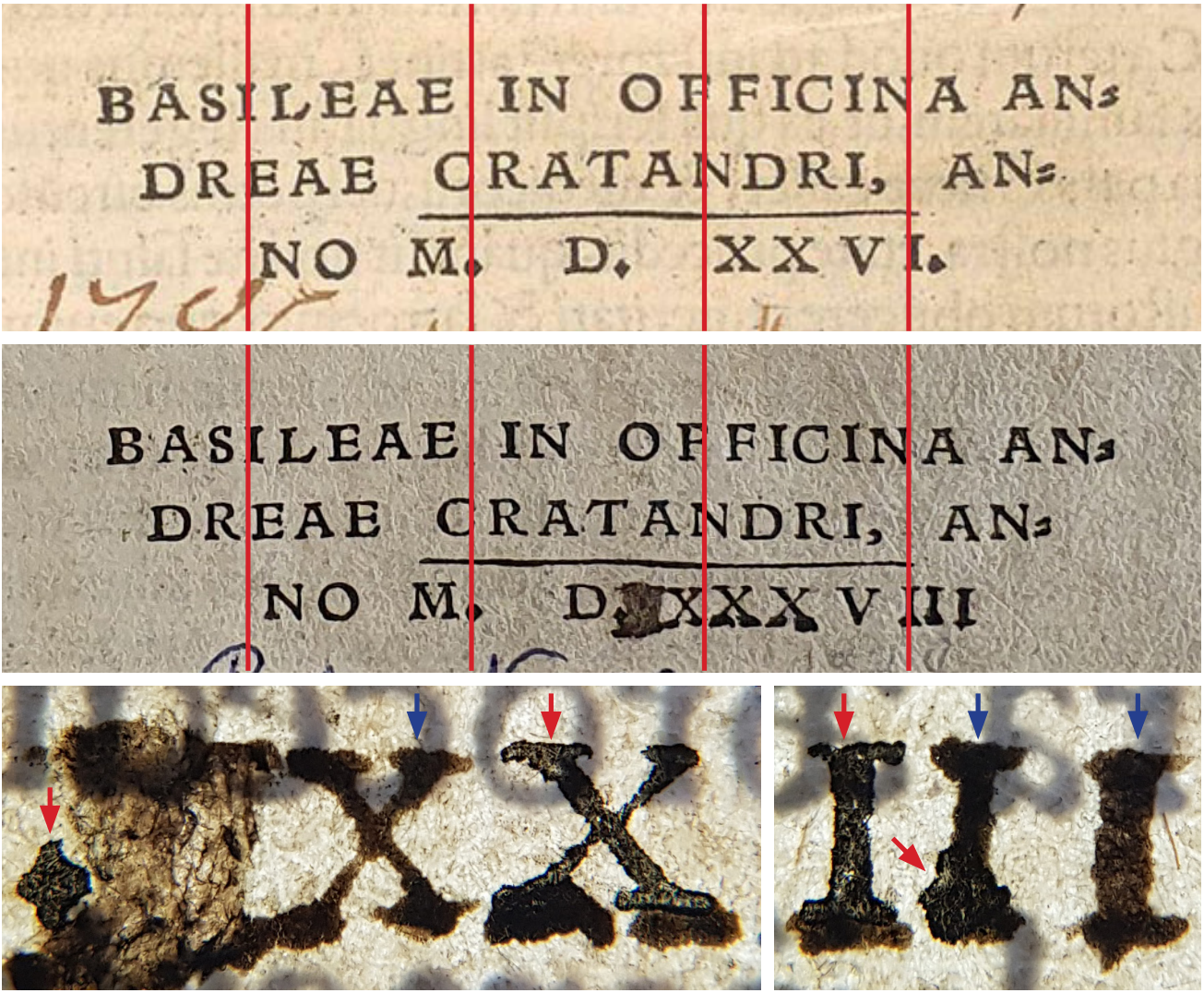

Figura 4 - Detalhes ampliados da folha de rosto da obra Hippocratis coi medicorvm omnivm (1526). Acima, comparação entre os exemplares da Universidade de Michigan (University of Michigan Library, Special Collections Research Center) e da Universidade de Brasília. Abaixo, detalhe ampliado do exemplar preservado na Biblioteca Central da Universidade de Brasília.

Tem-se, portanto, que a folha de rosto do exemplar da Universidade de Brasília apresenta informações relativas à datação do título registradas em dois momentos distintos. Sinalizada com setas vermelhas no detalhe da Figura 4 encontra-se a informação estampada em 1526 pela prensa de Cratander, enquanto os algarismos romanos adicionais, identificados com setas azuis, foram acrescentados em um momento posterior. De fato, obras associadas à prensa de Cratander no ano de 1538 mantiveram o padrão de espaçamento entre os algarismos romanos." Todavia, para além da quebra do padrão tipográfico, o acréscimo tardio da informação igualmente se confirma por meio de três características, a saber: (1) as diferenças na forma gráfica da letra X e (2) a falta de regularidade no alinhamento e no distanciamento entre as novas letras I - sendo a primeira delas intencionalmente mais aproximada do caractere já impresso para se sobrepor ao sinal de pontuação existente -, além (3) do comportamento da tinta no papel. As duas primeiras diferenças acima assinaladas não são compatíveis 
com o padrão de reprodução das letras projetadas em relevo nos tipos móveis metálicos à época da prensa manual. A regularidade esperada na forma gráfica dos glifos impressos, bem como o alinhamento que resulta do modo de composição das linhas alimentam a tese segundo a qual a informação suplementar foi adicionada posteriormente à mão. Essa tese se confirma ao se observar a última das três características. Note-se, na imagem ampliada, tanto a diferença de tonalidade e das propriedades da tinta absorvida pelo papel quanto a inexistência de regiões de acúmulo de tinta nos limites dos caracteres, sendo este um efeito eloquente da ação da prensa de tipos móveis, como se verá adiante. Ademais, para além dos argumentos de ordem gráfica e material, o estudo de outras obras produzidas no período comprova que a cercadura gravada em metal por Jakob Faber a partir dos desenhos de Hans Holbein havia se deslocado da Basileia para a oficina do impressor alemão Sebastian Gryphius, por sua vez estabelecido em Lyon, na França. ${ }^{12}$ Desse modo, o acréscimo tardio da informação suplementar no exemplar brasiliense da obra produzida na oficina de Cratander em 1526 foi feito à mão, com tinta de base aquosa, de forma que a data de 1538 registrada na peça impressa não corresponde ao ano de impressão do título.

A análise do exemplar brasiliense do Corpus Hippocraticum revela que um problema de registro bibliográfico encerra uma questão de ordem maior, relacionada à compreensão das características materiais e à confiabilidade das marcas gráficas presentes em artefatos impressos à época da prensa manual. $\bigcirc$ que elas de fato revelam? Nas quatro seções deste artigo, articulam-se paralela e intencionalmente dois planos investigativos com o propósito de apresentar o ganho analítico que o estudo da materialidade de impressos da Época Moderna, de sua produção gráfica coletiva e de seus processos de edição, bem como dos modos de organização textual e visual da informação registrada predominantemente em papel trazem para a pesquisa histórica. Em um primeiro plano, tem-se por objetivo familiarizar leitoras e leitores com aspectos mais gerais relacionados à produção de impressos no período. Todavia, uma vez que os produtos da prensa manual frequentemente apresentam uma configuração e exibem marcas particulares originadas em momentos distintos, o segundo plano investigativo deste artigo dedica-se à análise gráfica e material de exemplares paradigmáticos, majoritariamente pertencentes à coleção de obras raras da Biblioteca Central da Universidade de Brasília e impressos no continente europeu entre os séculos XVI e XVII. A restrição geográfica da origem dos artefatos aqui analisados justifica-se pelas características do acervo universitário brasiliense. Assim, ainda que estudos mais recentes de história do livro confiram importância à produção e à circulação em escala global de impressos na Época Moderna - considerando-se inclusive o 
13. Sobre obras impressas entre os séculos XVI e XVIII, tanto no mundo islâmico quanto no continente asiático, consulte-se, mais recentemente: Raven (2020).

14. Sobre o estabelecimento da prensa na América de colonização espanhola e sobre as dificuldades tipográficas para a elaboração de texto em línguas locais, cf. Garone Gravier (2010). Quanto à presença da prensa na colônia portuguesa, cf. Azevedo (2019); Barros (2012).

15. Cf. sobretudo Pearson (2020).

16. Cf. Pickwoad (2009, p. 284). pioneirismo da técnica no continente asiático ${ }^{13} \mathrm{e}$ as particularidades tipográficas de peças produzidas no continente americano ${ }^{14}$-, restringimo-nos ao espaço de contato mais frequente dos impressores da Basileia. Após analisar obras com características comparáveis ao Corpus Hippocraticum editado por Cratander em 1526, veremos que os artefatos impressos à época da prensa manual refletem padrões culturais, ao mesmo tempo que resultam de limites impostos pela técnica e por decisões de ordem econômica.

\section{FORMA E MATERIALIDADE DE ARTEFATOS IMPRESSOS NA ÉPOCA MODERNA}

Os produtos manufaturados nas oficinas de impressão entre os séculos XV e XVIII eram comercializados por editores, livreiros e mascates tanto na forma de estampas e folhas avulsas quanto na forma de cadernos de texto dobrados, por vezes entregues ao consumo imediato com poucos pontos de costura para assegurar o ordenamento provisório das páginas. Mas ocorre que diversos livreiros também ofereciam obras impressas de forma previamente encadernada, valendo-se frequentemente de material pouco dispendioso para unir e proteger as páginas de um título. ${ }^{15}$ De todo modo, contrariamente ao que ocorre no mercado de livros contemporâneo, as obras levadas à prensa manual deixavam as oficinas de impressão sem uma encadernação uniforme e por meio da qual se identificava o conteúdo das páginas impressas. Tal prática comercial se justificava, em primeiro lugar, em função da organização das atividades manufatureiras em diversas cidades no período, segundo a qual se reservava o ofício de inclusão das pastas rígidas, de seu revestimento e da costura aos encadernadores, em detrimento dos tipógrafos. Isso não impedia, todavia, que boa parte dos livreiros exercesse o duplo ofício. Em segundo lugar, esse mesmo padrão de produção e comercialização de artefatos impressos também se estabeleceu por motivos de ordem mais claramente econômica.

Como a comercialização de impressos na Época Moderna não se limitava às fronteiras do mercado local no qual o papel recebia a tinta, o produto da prensa precisava ser transportado. Os custos do transporte, por sua vez, cresciam de acordo com o peso e o volume adicionados às páginas impressas com a inclusão da encadernação. Ademais, ao cruzar fronteiras fiscais, impostos diferenciados poderiam incidir sobre a importação de livros encadernados, em detrimento das taxas alfandegárias cobradas pela circulação comercial de estampas e folhas avulsas ou cadernos de texto dobrados. ${ }^{16}$ Vistos 
em conjunto, esses dois fatores explicam os motivos pelos quais diversos volumes foram frequentemente submetidos a uma etapa adicional de finalização da manufatura impressa, não raro em um centro urbano mais próximo à região em que suas páginas eram comercializadas e consumidas - e não necessariamente produzidas. Uma vez sujeitas às variações regionais, a destreza do trabalho manual e a qualidade dos materiais nela empregados conferem não apenas volume, peso e valor econômico às peças impressas, mas também identidade e prestígio social ao artefato finalizado.

Um dos materiais mais frequentemente utilizados no período para revestir as pastas rígidas foi o couro animal, cuja origem, qualidade e coloração encontram-se diretamente associadas ao valor da encomenda. Adicionalmente, tecidos e bordados refinados também protegeram e decoraram volumes impressos. ${ }^{17}$ Disso resulta que diversos exemplares encadernados de um mesmo título não se caracterizam pela uniformidade da aparência. De fato, o material e os ornamentos aplicados ao revestimento das obras viram-se mais ou menos limitados em função do grau do investimento econômico, obedeceram a expectativas de consumo regionais, alteraram-se em função das transformações tecnológicas das ferramentas utilizadas no ofício dos encadernadores e acompanharam padrões visuais difundidos nas artes decorativas de cada período. Assim, a encadernação é vestígio material eloquente a partir do qual se pode concluir que a história de um artefato impresso à época da prensa manual não se identifica exclusivamente com a história de sua impressão.

Postos à vista no revestimento de volumes encadernados, brasões e iniciais gravadas em material nobre são elementos identificadores do percurso histórico das páginas impressas por coleções e, portanto, marcas de proveniência. Entretanto, tais encadernações de luxo - proporcionalmente mais bem preservadas - não constituíram a maior parcela numérica das peças produzidas no mercado de impressos do período. Com a expansão das atividades da prensa, proteções e materiais de revestimento mais modestos passaram a ocupar um espaço largamente cultivado pelo trabalho de encadernadores e livreiros, como é o caso da encadernação cartonada reproduzida na Figura 5. 


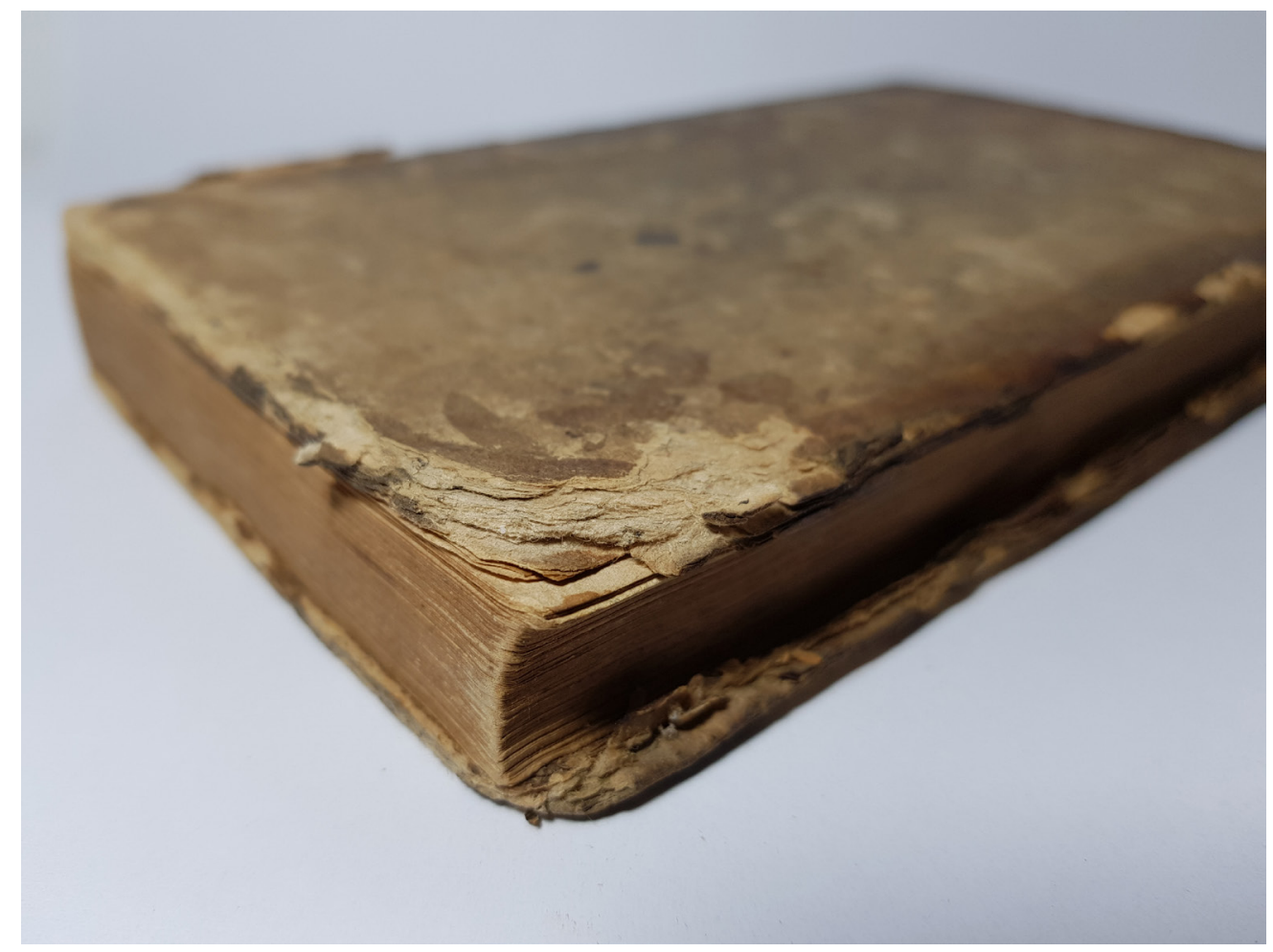

Figura 5 - Encadernação cartonada. Uz (1776). Acervo particular do autor.

Adicionalmente, impressos mais efêmeros - almanaques, calendários, anúncios reais, panfletos e folhas volantes, por exemplo - eram não apenas comercializados ou distribuídos, mas também frequentemente consumidos de forma solta ou com pontos provisórios de costura. Em função do uso imediato e intenso dessas peças, bem como do caráter efêmero da informação nelas impressa, é proporcionalmente baixo o número de exemplares preservados desses gêneros. Também raramente dadas à preservação eram as capas provisórias, impressas em papel e adicionadas costumeiramente aos números individuais de obras fasciculares, uma vez que eram destinadas ao descarte após passar pelas mãos de encadernadores e eventualmente livreiros que uniam os diversos números de um mesmo título. Assim, se a configuração material da encadernação de títulos impressos na Época Moderna pode, por um lado, identificar coleções e sinalizar intenções de preservação das páginas unidas, também pode, por outro, adicionalmente revelar vestígios da economia de descarte do suporte da informação. Tais vestígios evidenciam-se não apenas pela ausência de peças potencialmente provisórias em exemplares de um título comparados em série, mas também pela presença de peças descartadas em outros volumes preservados. 
Em função do custo elevado do suporte da informação, folhas de papel impressas ou manuscritas de interesse reduzido foram reutilizadas tanto no espaço doméstico - com o objetivo de proteger e preservar alimentos, por exemplo quanto nas oficinas de encadernadores e livreiros, nas quais fragmentos de obras impressas e manuscritos passaram a reforçar a lombada de novos títulos. É o que ocorre com a peça escrita à pena, de conteúdo e origem ainda não identificados, encontrada recentemente na estrutura da encadernação do exemplar pertencente ao acervo de obras raras da Biblioteca Central da Universidade de Brasília de uma obra impressa em Lyon no século XVI.

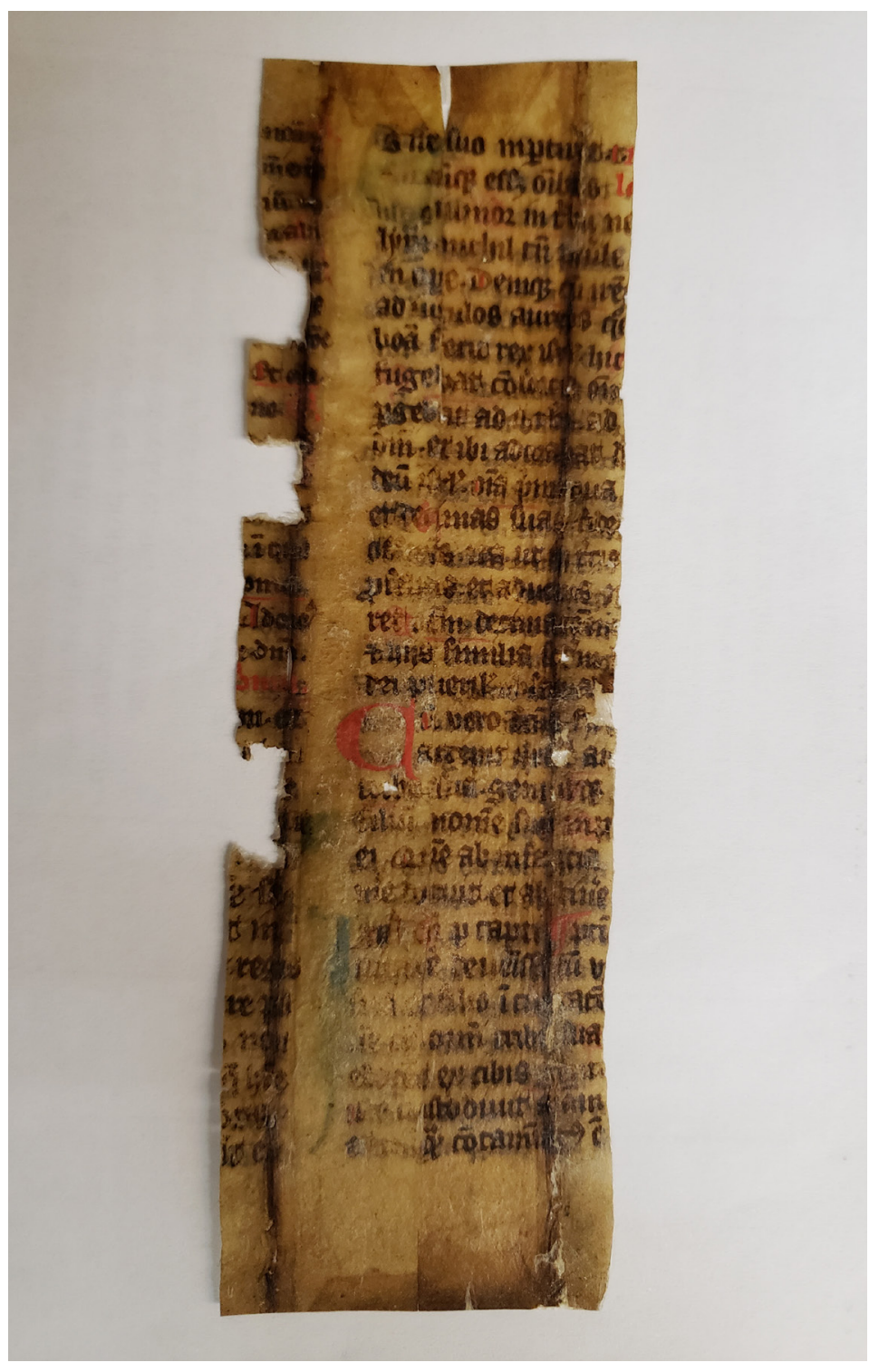

Figura 6 - Material utilizado para reforçar a lombada da obra Lexicon iuris sev epitome definitionum, \& rerum (1549). Manuscrito não identificado. Acervo da Biblioteca Central da Universidade de Brasília. 
Para além da costura dos cadernos de texto e da estruturação da lombada, uma das etapas de execução da encadernação requeria a introdução de folhas de guarda, ou seja, de folhas de papel que protegem o conteúdo da obra e que complementarmente asseguram a junção da capa ao miolo dos livros. Trata-se frequentemente de papel mais espesso adicionado pelas mãos do encadernador, de tal forma que ele raramente provém do mesmo lote utilizado na oficina de impressão. E uma vez que as folhas de guarda pertencem à estrutura da encadernação, elas devem ser descritas e analisadas como sev elemento integrante, e não como parte dos cadernos da obra impressa.

A diferença da qualidade e da origem das folhas de papel utilizadas para imprimir e guardar um título é eloquente, por exemplo, no exemplar da obra seiscentista Divinos, e humanos versos, preservado na Universidade de Brasília. As páginas impressas do texto de D. Francisco de Portugal encontram sustentação material no couro marrom da encadernação e na follha de guarda que, contra a luz, apresenta a imagem do brasão de armas oitocentista da República Federativa do Brasil. Diversos aqui revelam-se os materiais, as épocas e os agentes históricos presentes e responsáveis pela configuração contemporânea da peça preservada, de modo que artefatos impressos não são vestígios históricos apenas da sociedade que os produziu, mas também daquelas que neles deixou marcas de uso e promove a sua conservação.
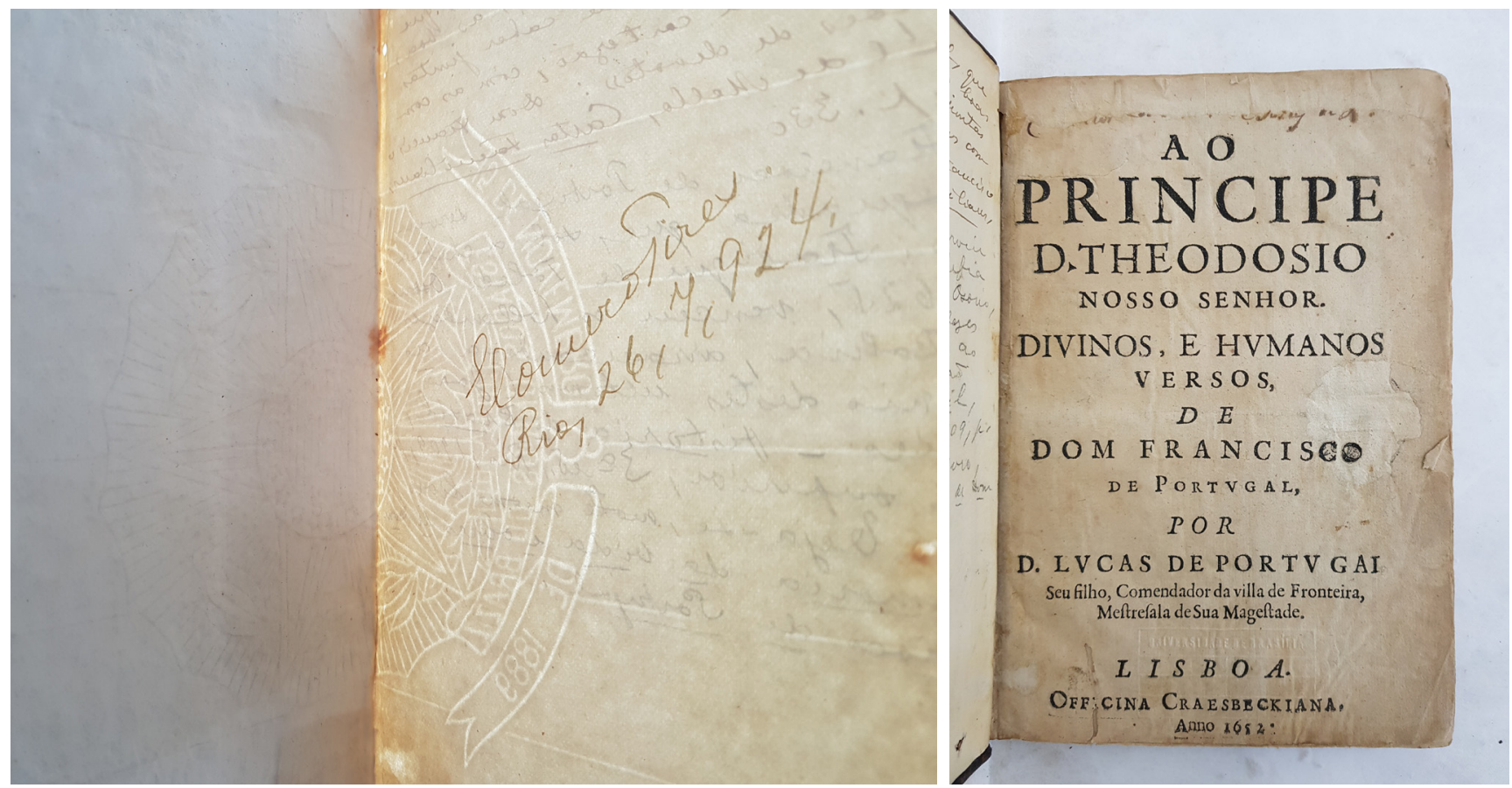

Figura 7 - Folha de guarda com marca d'água e folha de rosto da obra: Portugal (1652). Acervo da Biblioteca Central da Universidade de Brasília. 
Na Época Moderna, o papel não era o único suporte material da 18. Robinson (2014, p. 63). impressão. No entanto, ainda que pergaminho e eventualmente tecidos tenham 19. Needham (2017). sido igualmente levados à prensa, o período registra o predomínio vigoroso do papel na produção de impressos. Mesmo que em projetos gráficos mais complexos - com a presença de muitas gravuras e o uso de tipos móveis variados - diminuase proporcionalmente o peso econômico associado à aquisição de folhas de papel no cálculo do custo final dos produtos da prensa, elas não deixam de ser uma unidade de medida utilizada por impressores e editores para, respectivamente, organizar o trabalho desenvolvido nas oficinas e estimar os riscos do investimento econômico represado com a produção de um tífulo.

O papel destinado à impressão era geralmente fornecido aos impressores por editores e livreiros que controlavam e financiavam as etapas de produção de suas encomendas. Distinto na superfície do material utilizado para a escrita à pena, as folhas de papel consumidas nas oficinas de impressão se caracterizam por não apresentar polimento adicional para receber a tinta. Feitas de trapos de fibras têxteis, predominantemente algodão e linho, elas eram produzidas em moinhos cujo funcionamento dependia do acesso constante à água e nos quais ocorria a separação do material orgânico por critérios de textura e coloração. Em seguida, o trapo era rasgado em pequenos pedaços, fermentado e triturado, com o objetivo de desestruturar as fibras da celulose. Desse processo resultava uma pasta espessa que passava a ser recolhida com a ajuda da fôrma papeleira - instrumento feito de bordas de madeira conectadas por uma densa trama de fios metálicos, que por sua vez permitiam a passagem da água ao mesmo tempo que retinham a massa úmida. A essa etapa da produção do papel, sucediam-se diversas fases de secagem.

Do processo manual de produção do papel, decorrem algumas caraterísticas materiais importantes para a pesquisa histórica. Uma vez que a fôrma papeleira com a pasta de papel era segurada com as mãos, as dimensões da folha viram-se materialmente delimitadas pelas condições da ação do trabalho humano. A fôrma precisava ser manejada com destreza pelos braços daqueles que nela distribuíam uniformemente a matéria úmida. E como as fôrmas papeleiras tinham dimensões variadas em distintos moinhos, seus produtos acompanhavam as mesmas variações dimensionais.

Ainda que se registrem medidas mais frequentes das folhas de papel comercializadas no período, ${ }^{18}$ notam-se diferenças relevantes que ajudam a identificar padrões locais de produção e circulação do suporte material da informação à época da prensa manual, como recentemente destacado por Paul Needham. ${ }^{19}$ Todavia, a despeito da diversidade, em quaisquer dimensões a qualidade da matéria-prima fermentada influenciava no resultado final da produção do papel. Enquanto o puro 
20. Sobre a posição central da produção de lã na economia inglesa, sobretudo entre os séculos XVI e XVII, cf. Hentschell (2008).

21. Bidwell (2009, p. 200); Bidwell (2002, p. 583).

22. Id. (2009, p. 201). linho branco resultava em papel de boa qualidade, uma proporção comparativamente elevada de lã ou de tecidos tingidos no conjunto de trapos levados à fermentação produzia papel de coloração mais escura e de inferior qualidade. E iá que a lã era um material de presença mais constante em tecidos ingleses no período, ${ }^{20}$ o papel inglês é tendencialmente mais escuro e de qualidade inferior àquele manufaturado no continente, dando espaço para que as importações francesas dominassem o mercado britânico de papel até o final do século XVII. ${ }^{21}$ No século seguinte, predominam as importações dos centros produtores da mesma mercadoria localizados na península itálica e na região dos atuais Países Baixos. ${ }^{22}$ Mas para além de revelar transações comerciais, as escolhas operadas por livreiros e editores no que diz respeito à qualidade e ao custo do suporte material da informação relacionam-se diretamente com o poder aquisitivo do público destinatário, a intenção de prestígio associada à peça e a durabilidade presumida do consumo dos artefatos impressos. Desse modo, gêneros efêmeros tendem a ser impressos em papel de qualidade inferior, comparando-se àquele utilizado nas oficinas para produzir obras valorizadas pela comunidade letrada renascentista, como é o caso do Corpus Hippocraticum impresso na cidade da Basileia em 1526.

De toda forma, independentemente da qualidade e da região na qual as folhas de papel tenham sido produzidas, elas apresentam características materiais que decorrem da atividade manufatureira. Tais características são exploradas pela pesquisa histórica com o objetivo de identificar a proveniência do papel e estabelecer hipóteses de trabalho relacionadas ao processo de produção das peças impressas. Uma das primeiras e mais eloquentes características materiais que saltam aos olhos de pesquisadoras e pesquisadores contemporâneos é a trama que os fios metálicos da fôrma papeleira impõem à estrutura física do papel. Denominam-se linhas d'água as pequenas variações de espessamento do papel que resultam do contato dos fios metálicos com sua massa ainda úmida. Elas produzem uma textura nervurada em toda a superfície da folha e podem ser vistas de modo mais evidenciado quando o papel é colocado contra a luz. As linhas mais espessas e espaçadas, localizadas na posição vertical da folha de papel, são denominadas pontusais, enquanto as linhas paralelas mais delgadas e próximas entre si, encontradas na dimensão horizontal da folha, são denominadas vergaturas. Para além das linhas horizontais e verticais características do papel avergoado, alguns produtores acresciam à trama das fôrmas marcas particulares a partir das quais seus produtos poderiam ser identificados. Chamadas de marca d'água, ou filigrana, elas constituem mais uma evidência material para se estabelecer a origem do produto impresso.

As marcas d'água resultam da presença de um desenho ou símbolo feito em metal e posicionado no centro de uma das metades da folha, de modo mais 
elevado sobre os fios metálicos da fôrma papeleira. À segunda metade da folha poder-se-ia acrescentar uma contramarca, frequentemente evidenciando as iniciais do fabricante de papel. Tem-se, por conseguinte, que a marca d'água e eventualmente a contramarca são as regiões de menor espessura - e, portanto, de maior transparência - da folha de papel, como se percebe nas páginas do Corpus Hippocraticum impresso por Cratander em 1526 (Figura 8).
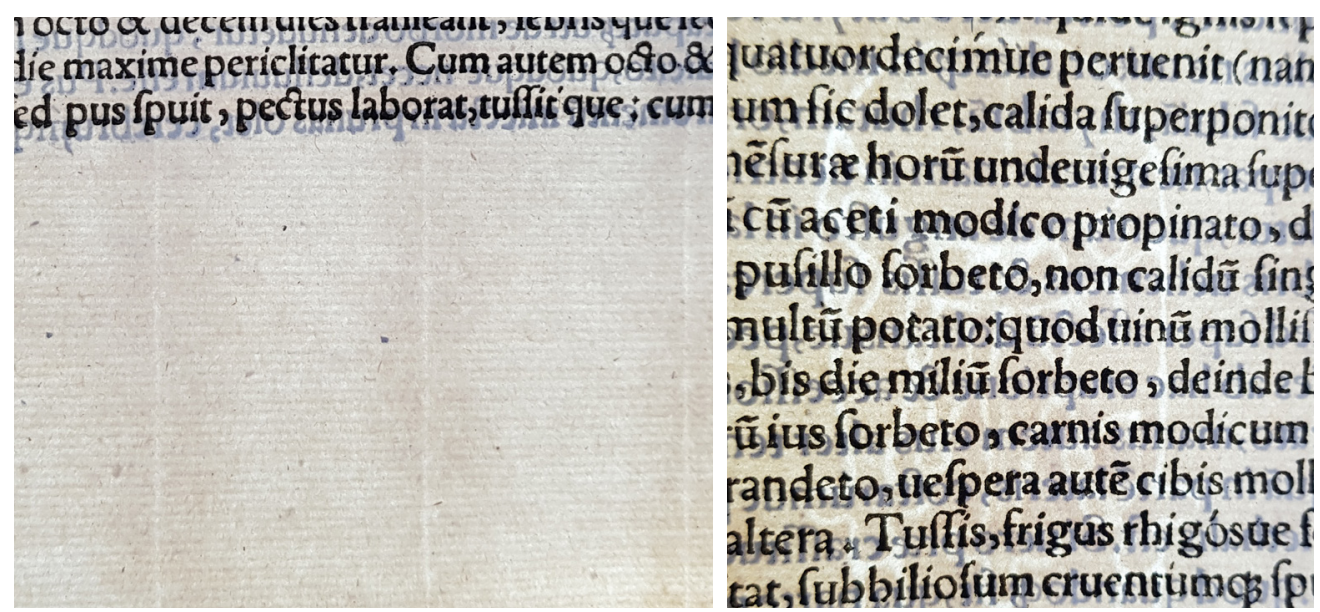

Figura 8 - Linhas d'água e marca d'água em papel avergoado do século XVI. Hippocratis coi medicorvm omnivm (1526). Acervo da Biblioteca Central da Universidade de Brasília.

Considerando-se as marcas deixadas no papel, pode-se estabelecer hipóteses iniciais de trabalho relativas à datação e à localização de sua produção. ${ }^{23}$ No entanto, alguns limites importantes devem ser observados. Em primeiro lugar, trata-se de limites apresentados pelas circunstâncias históricas da produção do papel. Conhecido é o caso de uma determinação francesa de 1741 segundo a qual os moinhos deveriam incluir o ano de produção da manufatura na fôrma papeleira. Mas, uma vez que a norma não indicava a necessidade de alteração periódica da informação, o ano de 1742 figurou por largo tempo em distintos estoques de papel. ${ }^{24}$ Adicionalmente, papel de inferior qualidade produzido para finalidades diversas - como embalagem de outros produtos - raramente apresenta uma marca d'água, sobretudo ao longo do século XVIII. Em segundo lugar, acrescentam-se limites impostos pelo uso constante dos instrumentos empregados na produção do papel, uma vez que eles sofrem desgastes, de modo a acarretar leves modificações ora no desenho das marcas d'água, ${ }^{25}$ ora na trama dos fios. Tais desgastes resultam em pequenas variações das evidências materiais deixadas no produto de um mesmo moinho. Ademais, também as folhas produzidas em diferentes momentos podem apresentar variações na aparência que decorrem das condições de armazenamento e de tratamento do papel, assim como também da
23. Para identificação de papel sem marca d'água, há estudos que analisam a estrutura das vergaturas com o objetivo de particularizar, por exemplo, a densidade da trama deixada no papel pelos fios. Cf. Meulen (1984). Já sobre a presença de vergaturas, pontusais e marca d'água em papéis utilizados na Bahia no início do século XIX, cf., por exemplo, Lose; Mazzoni (2020, p. 139-140).

24. Chamberlain (2013, p. 123).

25. Stevenson (1962). 
26. Chamberlain (2013, p. 125-129).

27. Cf. Robinson (2014, p. 63-64). qualidade da água e da quantidade de minério presente na pasta, algo variável em função das precipitações climáticas, por exemplo. ${ }^{26}$

Mas, ainda que o reconhecimento seguro da proveniência e da identidade entre as folhas de um mesmo lote de papel apresente dificuldades significativas, diferenças entre elas não deixam de ser elementos igualmente importantes na compreensão da produção de impressos. Enquanto a presença de marcas d'água distintas em um mesmo volume indica com segurança o uso de estoques distintos de papel em uma mesma empreitada, pode-se analogamente relacionar as etapas de trabalho envolvidas na produção de produtos gráficos diferentes unidos social e economicamente, todavia, pelo uso de um mesmo estoque de papel. ${ }^{27}$ Note-se que versos de ocasião e panfletos de rápida impressão frequentemente interrompiam a produção de obras mais complexas e dispendiosas, de modo a garantir o retorno mais rápido do investimento econômico depositado nas tarefas em curso nas oficinas. Assim, peças simples ou cadernos de textos suplementares adicionados a títulos estocados poderiam, eventualmente, ser impressos em folhas já disponíveis. Também nesses casos, algumas situações particulares se colocam.

Cadernos de texto preliminares eram quase que certamente compostos e levados à prensa após a impressão das páginas centrais, de modo que as oficinas por vezes se valiam de um estoque de papel distinto daquele utilizado para a impressão dos cadernos principais. A composição mais tardia do primeiro caderno de uma obra garantia atualidade ao título, como muito se procurou demonstrar nas dedicatórias e nos prefácios. Já o uso de papel de estoque diferente em um mesmo título era mais frequente nos casos em que editores comercializavam obras encalhadas apenas com a substituição da folha de rosto, por vezes ainda acompanhada de um novo caderno de texto preliminar. Trata-se de uma estratégia comercial adotada na Época Moderna com o propósito de sugerir a disponibilidade de uma nova edição, revisada e ampliada. Essa prática nos convida a adotar uma postura cautelosa no exame do conjunto das páginas levadas à prensa, como ficará mais evidente ao final deste artigo, após se apresentar as dificuldades de definição de estados, variantes e tiragens especiais de edições manufaturadas no período. Por enquanto, deve-se estabelecer apenas uma regra geral: não é seguro fiar-se a um único elemento a partir do qual se pode garantir a autenticidade e estabelecer a proveniência de artefatos impressos. Deve-se sempre considerar um conjunto vasto de evidências, de modo a se somar às considerações relacionadas à produção do papel outras propriedades materiais, características gráficas, particularidades textuais e configurações editoriais das peças impressas, como vimos na obra editada por Cratander e 
ainda será discutido com mais profundidade na próxima seção deste artigo. Contudo, antes de avançarmos nessa direção, retomemos a ideia segundo a qual a variedade das dimensões de folhas de papel tem como consequência direta o fato de que os impressos que circularam na Época Moderna apresentam tamanhos distintos. Sobretudo no caso dos livros, seus formatos não são definidos pelas dimensões materiais da página, mas sim pelo número de vezes em que a folha de papel foi dobrada para constituir um caderno.

Denomina-se imposição a operação por meio da qual as páginas de um caderno de texto foram dispostas e compostas tipograficamente, observando-se a sequência da informação na organização da folha inteira de papel. Antes de receber as dobras, portanto. Trata-se de uma atividade complexa e fundamental para garantir a qualidade dos produtos de uma oficina, bem como para auxiliar no cálculo estimado de consumo dos principais insumos da impressão, como papel e tinta, sendo este o motivo pelo qual a ela se dedica uma série de manuais de impressão seiscentistas e setecentistas. ${ }^{28}$ Esse é o caso, por exemplo, de um volume impresso em 1743 por Christian Friedrich Geßner29 e destinado à instrução de impressores de língua alemã, operada com variações regionais já há mais de dois séculos nas oficinas de Cratander, Curio, Froben e Bebel. Nele, confere-se importância à matéria em texto e em imagem. Como se pode acompanhar com ajuda das gravuras reproduzidas na Figura 9, o formato in-folio é a imposição que resulta em quatro páginas de impressão, numeradas de um a quatro. Esse é o formato das obras impressas por Curio em 1523 e por Cratander e Bebel em 1526 que apresentam a mesma cercadura em relevo gravada por Jakob Faber. Já o formato in-quarto é imposição que resulta em oito páginas, enquanto que o formato in-octavo dá aos dois lados da folha de papel dezesseis páginas de impressão. Aqui, as páginas dedicadas por Geßner à imposição comprovam que a folha de papel não era apenas uma unidade econômica, mas também de organização do trabalho de tipógrafos e compositores envolvidos na produção de impressos à época da prensa manual.
28. Sobre os manuais de impressão da Época Moderna, consulte-se: Araújo (2020a).

29. Geßner (1743). 

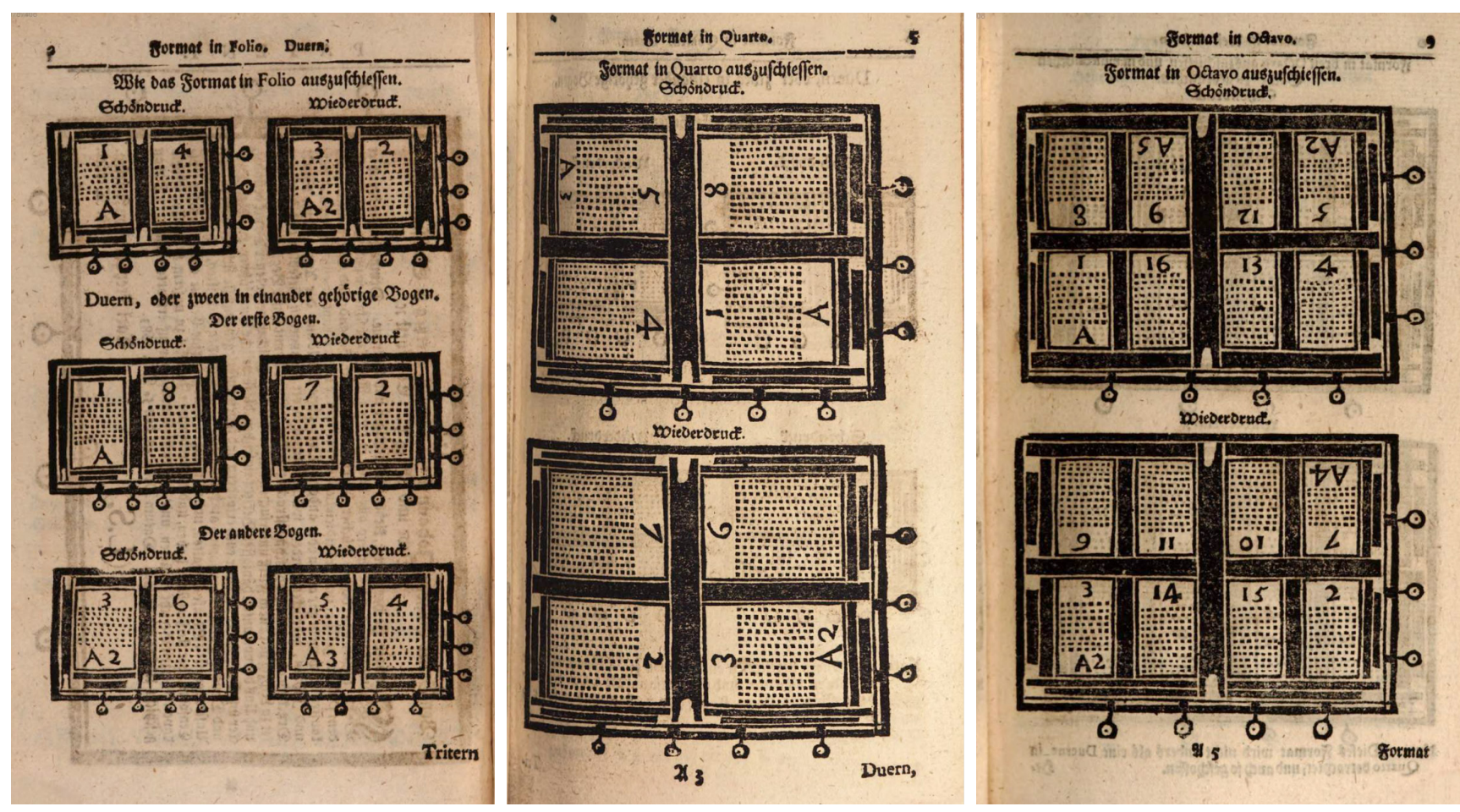

Figura 9 - Imposição nos formatos in-folio, in-quarto e in-octavo. Geßner (1743). Exemplar da Bayerische Staatsbibliothek, Munique.

Já que as dimensões materiais dos produtos da prensa manual são um dado insuficiente para determinar seus formatos, deve-se observar a posição dos pontusais. Note-se que, no caso da imposição in-folio, o texto de cada página impressa na folha inteira encontra-se paralelamente à largura do papel. Nesse caso, os pontusais localizam-se obrigatoriamente na posição vertical do papel, e a filigrana ocupa o centro de uma das páginas. Nas obras in-quarto, verifica-se que o fluxo de leitura do texto na página impressa antes de receber as dobras e os cortes se encontra paralelamente à altura do papel, de forma que os pontusais se apresentam na posição horizontal e a marca d'água revela-se dividida ao meio, na região da costura. Um terceiro formato, in-octavo, apresenta os pontusais na mesma posição da imposição in-folio, mas a marca d'água surge em posição distinta. Coincidentes com os limites das folhas abertas ou cortadas ao meio podem ser baladas, folhas volantes ou anúncios de rápida produção e distribuição, impressos normalmente apenas em uma das faces do papel. De todo modo, ainda que o formato de impressos produzido entre os séculos XV e XVIII não seja definido por suas dimensões, notam-se tendências de proporção na forma das peças: volumes in-folio e in-octavo são mais claramente verticais, enquanto o formato inquarto apresenta proporções comparativamente menos verticalizadas. Postos nas 
mãos de leitoras e leitores, formatos reduzidos encontram fácil amparo e escondemse rapidamente de olhares vigilantes e inesperados, ao passo que largos e pesados volumes requerem preferencialmente um anteparo para a leitura, enquanto peças impressas em uma só face se davam mais fácil e adequadamente à exposição pública. Assim, a forma do artefato impresso sugere - ao mesmo tempo que limita - as condições de uso da informação.

\section{MARCAS GRÁFICAS E VESTÍGIOS MATERIAIS NAS PÁGINAS IMPRESSAS}

Tipos móveis são blocos de metal fundido que apresentam na face, em relevo, um caractere invertido destinado à reprodução. Nas primeiras décadas de funcionamento da prensa de tipos móveis no continente europeu, a forma das famílias tipográficas poderia particularizar o resultado gráfico das páginas produzidas em uma oficina de impressão, uma vez que as matrizes eram frequentemente propriedade das oficinas. Mas sobretudo a partir da segunda metade do século XVI30 o comércio de tipos móveis fundidos sinaliza uma tendência de difusão e consolidação de padrões, ainda que muito variados, da forma gráfica dos caracteres.

Frente à variedade crescente dos tipos e para facilitar o trabalho dos compositores, os diversos tipos móveis de uma mesma família eram organizados em caixas tipográficas, que por sua vez abrigavam um número maior de caracteres também denominados glifos - do que a quantidade de letras do alfabeto. $\bigcirc$ número elevado de glifos decorre não apenas da presença de ornamentos, mas também de ligaduras e abreviações frequentes na tradição manuscrita que se viram gravadas em um único bloco de metal, formando, portanto, um só caractere. Contribuem ainda para elevar o número de caracteres presentes nas caixas as variações na forma da letra $s$, frequentes nas peças manuscritas e igualmente incorporadas pela tradição tipográfica à época da prensa manual. Nota-se o uso tendencialmente regular da letra s em sua forma mais alongada - designada s longo - no meio das palavras, enquanto a forma curta, de dupla curva do grafema s, é mais costumeiramente adotada no início e no final das palavras, em detrimento da variante alográfica, como se pode reconhecer na imagem ampliada de uma página da edição de Cratander do Corpus Hippocraticum publicado na Basileia em 1526 (cf. Figura 10). Em transcrições contemporâneas de documentos impressos no período nos quais ocorrem variações na forma da letra $s$, recomenda-se adotar a forma curta de modo uniforme.
30. Para o caso francês, cf. Vervliet (2008, p. 13). Consulte-se, também: Garone Gravier (2014, p. 127). 
31. Cf. Davies (1996).

32. Para compreender as equivalências entre diferentes classificações de tipos e verificar a normatização da nomenclatura tipográfica em língua portuguesa, cf. Farias (2016).

33. Araújo (2020b, p. 11). iperian nec ueriorinusicp is; prudentibus, gnaris'ue : quod opificum $\&$ ar : 2 perfecta, plena funt, plenéue pera Ca . Cum deficientia praterea, diminutáue quadam artifi çtis dãda fr.nt. Per aliis sutem artes fabrefacta, unibus demonftrabit+qua uero per medicam ar quadam pramifia, quadam præfer Soratio do Mala patentic n nouerunt, quidam morbi non in latenti, occul paucafunt; cors itra, \& multi.Quæ uero mala rubra funt, prift $=$ tra, que nó pas t: fo ecie enim \& uifu, \& tactu fenfum duricia, tent, multa. :́s calida, qux frigida, quorum fingulorum præ

Figura 10 - Exemplos de ligaduras, também designadas ligaturas (em vermelho), s longos (em verde) e s curtos ou de dupla curva (em azul) na obra Hippocratis coi medicorvm omnivm (1526, p. 3). Acervo da Biblioteca Central da Universidade de Brasília.

Na imagem ampliada do texto reproduzido na Figura 10, percebe-se o uso de tipos móveis romanos e itálicos. Esses primeiros tipos resultam do esforço operado por tipógrafos e impressores no início das atividades da prensa manual que procuravam emular a forma caligráfica de manuscritos humanistas. ${ }^{31}$ Todavia, entre os séculos XV e XVIII, os textos que utilizam o alfabeto latino são frequentemente compostos ora com tipos móveis romanos e itálicos, ora com tipos góticos. ${ }^{32}$ Ainda que tais variações não registrem oposições universais, as escolhas operadas por tipógrafos, editores e mais raramente autores refletem uma tendência verificada no período de reservar os tipos móveis romanos e itálicos para imprimir textos em latim, enquanto o desenho mais condensado dos tipos góticos - caracterizados sobretudo pela presença marcante de hastes alongadas e frequentemente quebradas das letras que deixam uma mancha impressa no papel mais carregada de tinta ${ }^{33}$ - identificava preferencialmente, sobretudo ao norte dos Alpes, o uso do idioma vernáculo. De fato, essa tendência se verifica nas obras latinas levadas à prensa na Basileia por Valentino Curio em 1523, por Johann Bebel em 1526 e por Andreas Cratander no mesmo ano: os três títulos que apresentam gravuras na folha de rosto estampadas a partir da mesma matriz foram impressos com tipos móveis romanos e itálicos (cf. Figura 2).

Nas oficinas, as páginas eram compostas manualmente pelo compositor, linha por linha, cabendo àqueles que se ocupam do ofício da impressão entintar a superfície em relevo dos tipos móveis. Mas tanto as características do metal quanto a pressão exercida pelas peças metálicas contra o papel exigiram uma solução técnica particular para o uso satisfatório da tinta nas oficinas de impressão. Na Época Moderna, a tinta com a qual as penas registravam os 
traços guiados pela mão no suporte material da escrita era de base aquosa, ${ }^{34}$ de modo que suas características não se adequavam à ação da prensa. $\bigcirc$ motivo era claro: a solução não se acomodava uniformemente na região elevada dos tipos móveis que deveria receber a tinta.

As dificuldades com as propriedades do veículo da escrita eram conhecidas nos círculos letrados, interessados em testar receitas, por exemplo, para que a tinta apropriada à ação da pena não congelasse no inverno. Pois eis que os segredos para combater tal inconveniente passaram a ser revelados em obras de caráter prático que circularam na forma impressa: dever-se-ia adicionar ao meio aquoso algumas gotas de uma solução alcoólica conhecida pelo nome de aqua vita. ${ }^{35}$ Mas segredos dessa ordem difundiram-se de modo seguro no papel graças à viscosidade e às demais propriedades do veículo oleoso que passou a conferir estabilidade ao comportamento da tinta destinada à impressão com tipos metálicos já desde o século XV. De todo modo, parte significativa das obras impressas na Época Moderna conjuga informações registradas à tinta no suporte da informação tanto pela ação mecânica da prensa quanto pelo movimento das mãos. Frequentes são as anotações deixadas pela pena de leitores do período à margem do texto impresso. Adicionalmente, em função de eventuais perdas ou supressão de material impresso, alguns exemplares podem também apresentar reintegrações cromáticas tardias de páginas inteiras ou de passagens ausentes nos volumes. A Figura 11 ilustra o caso de uma reintegração cromática, feita a nanquim, tanto na folha de rosto quanto de páginas inteiras adicionadas ao exemplar pertencente ao acervo de obras raras da Universidade de Brasília da obra Dialogos de Dom Frey Amador Arraiz, publicada em Portugal na primeira década do século XVII. ${ }^{36}$ Aqui, deve-se especialmente atentar para as diversas etapas temporais de registro da informação atualmente sedimentadas na peça impressa.

A Figura 12 apresenta de forma ampliada os vestígios materiais deixados pelo uso de três tipos de tinta aplicados em momentos distintos no papel. Claras são as diferenças entre a cobertura e a uniformidade das tintas preta e vermelha utilizadas para a impressão de tipos móveis, identificadas com as setas vermelhas; a tinta de base aquosa utilizada no registro manuscrito feito na Época Moderna, sinalizada com as setas em verde; e a tinta nanquim aplicada em um momento muito posterior na folha de rosto, e aqui destacada por meio das setas azuis. ${ }^{37} \mathrm{Um}$ pouco mais adiante, veremos ainda com mais detalhes como se comporta a tinta de base oleosa no momento da impressão. Por enquanto, destaque-se apenas como a tinta metálica e aquosa utilizada com a pena frequentemente é absorvida de forma mais profunda pelo papel, comprometendo a utilização do verso da folha ou, com o tempo, ocasionando potencialmente a corrosão do suporte. Esse efeito
34. Sobre as características plásticas, químicas e mecânicas das tintas em meio aquoso e oleoso, cf. Almada (2018) e Almada; Monteiro (2019, p. 17)

35. Plat (1594, p. 38).

36. ARAÚJO, André de Melo; LOURENCO, Néria; GREENHALGH, Raphael Diego (eds.). Obras raras da Biblioteca Central da Universidade de Brasília: séculos XVI e XVII. Brasília, DF: Editora Universidade de Brasília, 2021. No prelo. Agradeço a Márcia Almada pelos valiosos comentários sobre este caso particular.

37. De forma análoga, o mesmo procedimento manual foi adotado para completar a informação registrada em vermelho na folha de rosto do título seiscentista. O comportamento da tinta vermelha aplicada ao papel na área restaurada é distinto daquele que se observa na região tipografada. 
Figura 11 - Folha de rosto da obra Dialogos de Dom Frey Amador Arraiz (1604). Acervo da Biblioteca Central da Universidade de Brasília.

Figura 12 - Detalhes ampliados da follha de rosto da obra Dialogos de Dom Frey Amador Arraiz (1604). Acervo da Biblioteca Central da Universidade de Brasília. se encontra ilustrado na Figura 13, que reproduz um detalhe da folha de rosto de outro exemplar da mesma obra, os Dialogos de Dom Frey Amador Arraiz, no qual se percebe a diferença de comportamento no papel da tinta utilizada para a escrita à pena e daquela adotada na oficina de impressão.
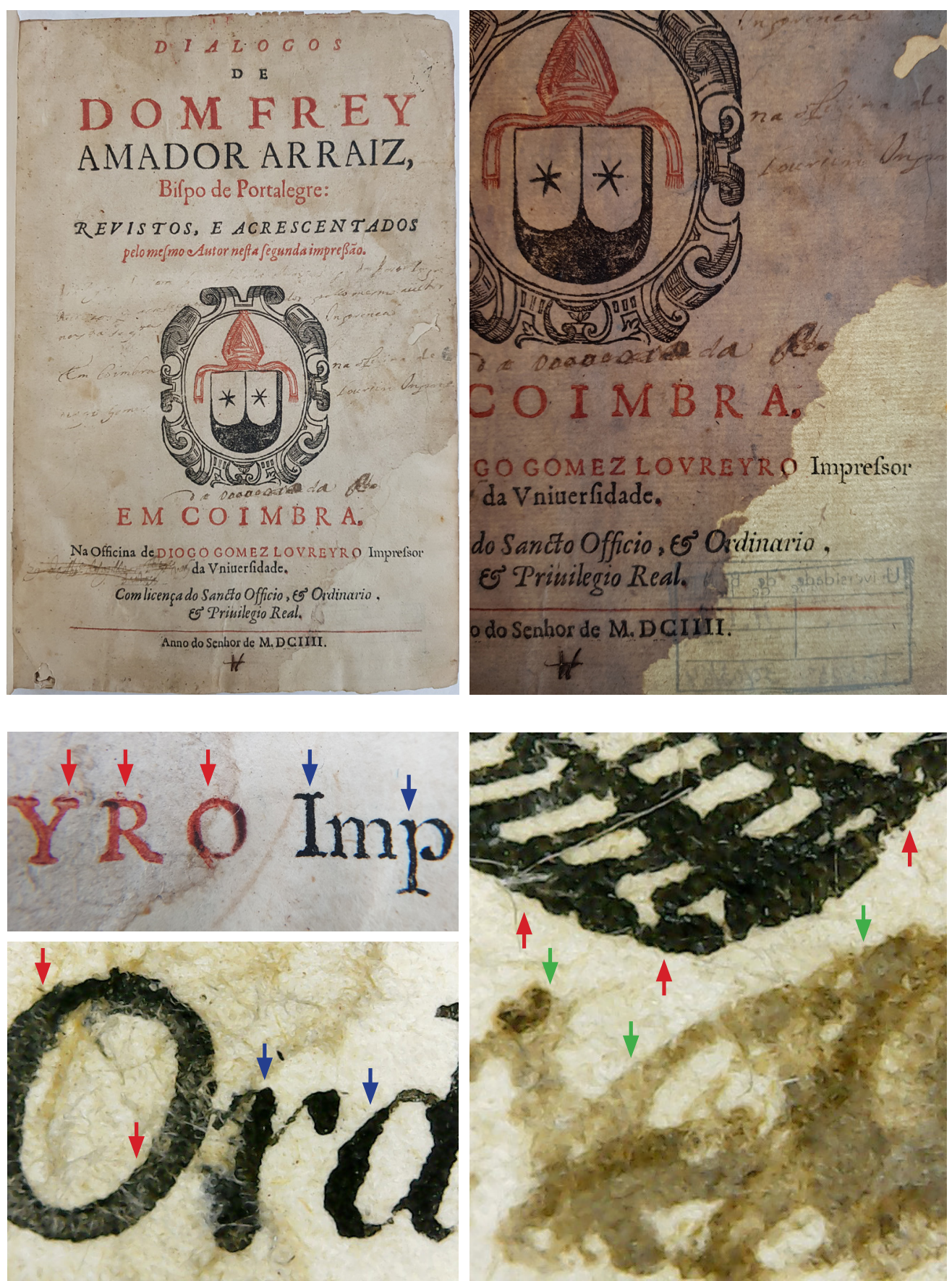


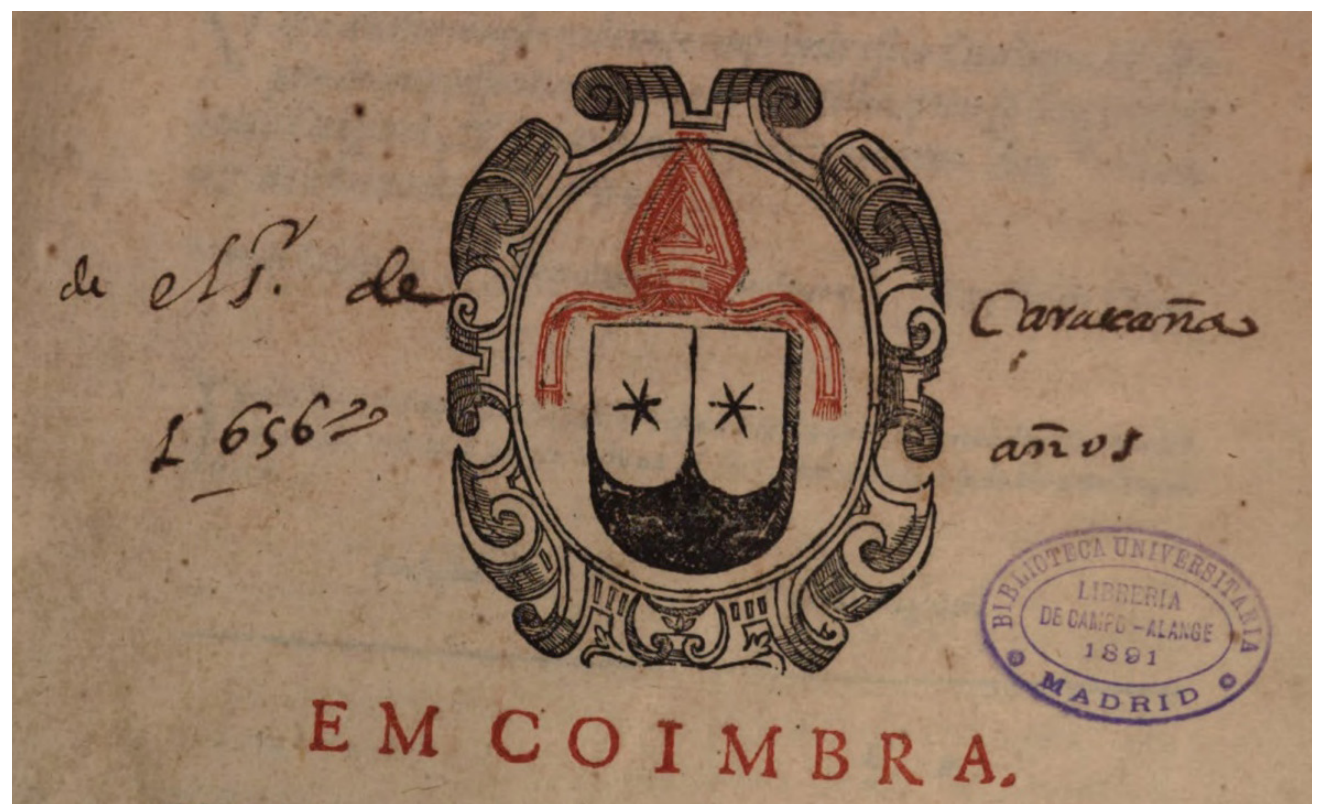

38. DiAlOgOS de Dom Frey Amador Arraiz [1604]. Hathi Trust, [s. l.], 2020. Disponível em: $<$ https://bit. ly/3vEiwC8>. Acesso em: 14 out. 2020.

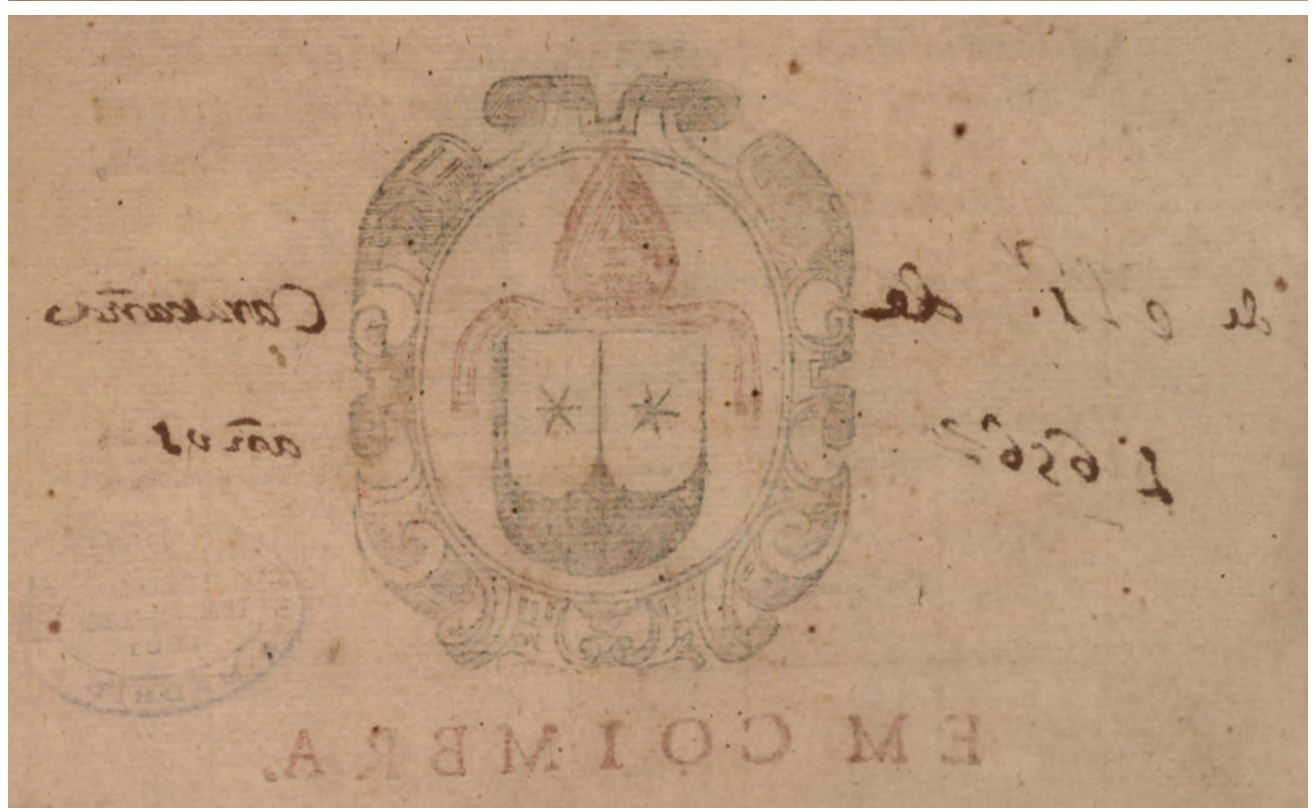

Figura 13 - Dialogos de Dom Frey Amador Arraiz (1604). Imagens de propriedade da Universidade Complutense de Madrid. 38

Tradicionalmente, o início da jornada de trabalho de aprendizes no ofício da impressão se ocupava da fabricação da tinta. Todavia, diversos impressores passaram a encomendar o produto para se livrar dos odores e de eventuais acidentes com o fogo que o preparo trazia para suas oficinas. Como os custos, seja com a produção ou com a compra da tinta, eram proporcionalmente elevados, produtos e insumos de qualidade 
39. Moxon (1683, p. 314).

40. Araújo (2020b, p. 3).

41. Ibid. (2020b, p. 8). inferior frequentemente se apresentavam como uma saída tentadora para reduzir o preço final dos impressos ou equilibrar temporariamente o orçamento das oficinas. No mercado de impressos, a concorrência era fortemente acirrada - como vimos ao acompanhar os produtos das prensas de Cratander, Curio, Froben e Bebel nas décadas de 1520 e 1530 - e as falências, uma ameaça constante. Para enfrentar as dificuldades sazonais de produção e otimizar o uso dos insumos da prensa, o impressor inglês Joseph Moxon recomendava que, se a tinta estivesse muito dura, "como às vezes em um clima muito frio", dever-se-ia então adicionar um pouco de tinta mais fresca, com o intuito de amaciá-la. ${ }^{39}$ Ou seja, aproveitar ao máximo o material disponível e obter a consistência esperada do veículo da informação não era um problema exclusivo da tinta adequada ao uso da pena. E, uma vez que a tinta à base de óleo não era absorvida pelo papel com a mesma intensidade que a solução aquosa, as folhas precisavam ser umedecidas pelos aprendizes antes de serem levadas à prensa.

Para além das estratégias de economia dos insumos, igualmente importante para a rentabilidade dos negócios editoriais do período era assegurar a relevância e a atualidade das peças comercializadas por livreiros e mascates. Com o objetivo de registrar a atualização da informação de obras que demandavam longas etapas de produção, o último caderno de texto impresso era frequentemente aquele no qual se apresenta o conjunto da obra. Mas antes mesmo de folhear prefácios e dedicatórias atualizados, o público leitor se deparava com uma folha de rosto. A folha de rosto é o dispositivo gráfico por meio do qual editores e impressores identificavam e apresentavam os produtos da prensa, bem como orientavam as primeiras expectativas dos leitores quanto à natureza das obras disponíveis em papel. ${ }^{40}$ Esse é o caso da informação presente nas três folhas de rosto impressas na Basileia por Curio, Cratander e Bebel (cf. Figura 2). Como se nota também nesses casos, usuais na Época Moderna são os títulos extensos, que preenchem a página inicial das obras e apresentam elementos de publicidade dos agentes envolvidos na produção do artefato. Sobretudo no século XVII, as folhas de rosto de obras mais elaboradas poderiam ainda ser acompanhadas de um frontispício. Embora existam situações de difícil distinção entre as funções dessas duas peças gráficas, deve-se procurar diferenciá-las. Geralmente, o frontispício é a única ilustração de uma obra e resulta, portanto, do trabalho de artistas, enquanto que a folha de rosto - também denominada página de rosto - apresenta o resultado do trabalho operado exclusiva ou predominantemente na oficina de impressão. Ademais, o frontispício se encontra preferencialmente de frente para o texto em uma obra encadernada, de modo a ocupar a posição do verso da primeira folha de papel inserida logo após a guarda, ao passo que as folhas de rosto são normalmente compostas com tipos móveis e impressas predominante ou exclusivamente em relevo no recto da primeira página integrada ou pertencente ao caderno de texto inicial. ${ }^{41}$ 


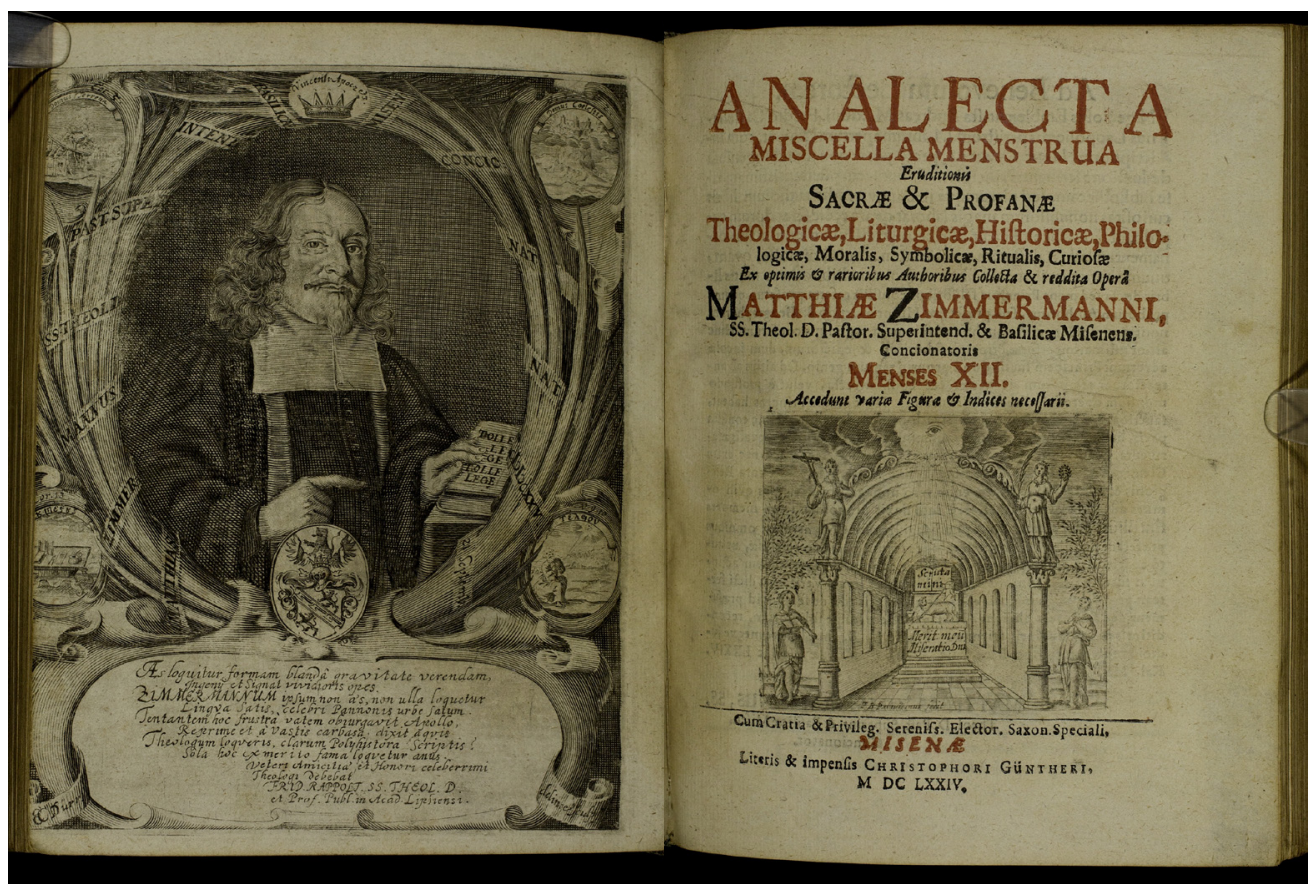

Figura 14 - Frontispício e folha de rosto da obra: Zimmermann (1674). Acervo da Niedersächsische Staats- und Universitätsbibliothek Göttingen [n. cat.: 8 H E UM 344/54 (2)].
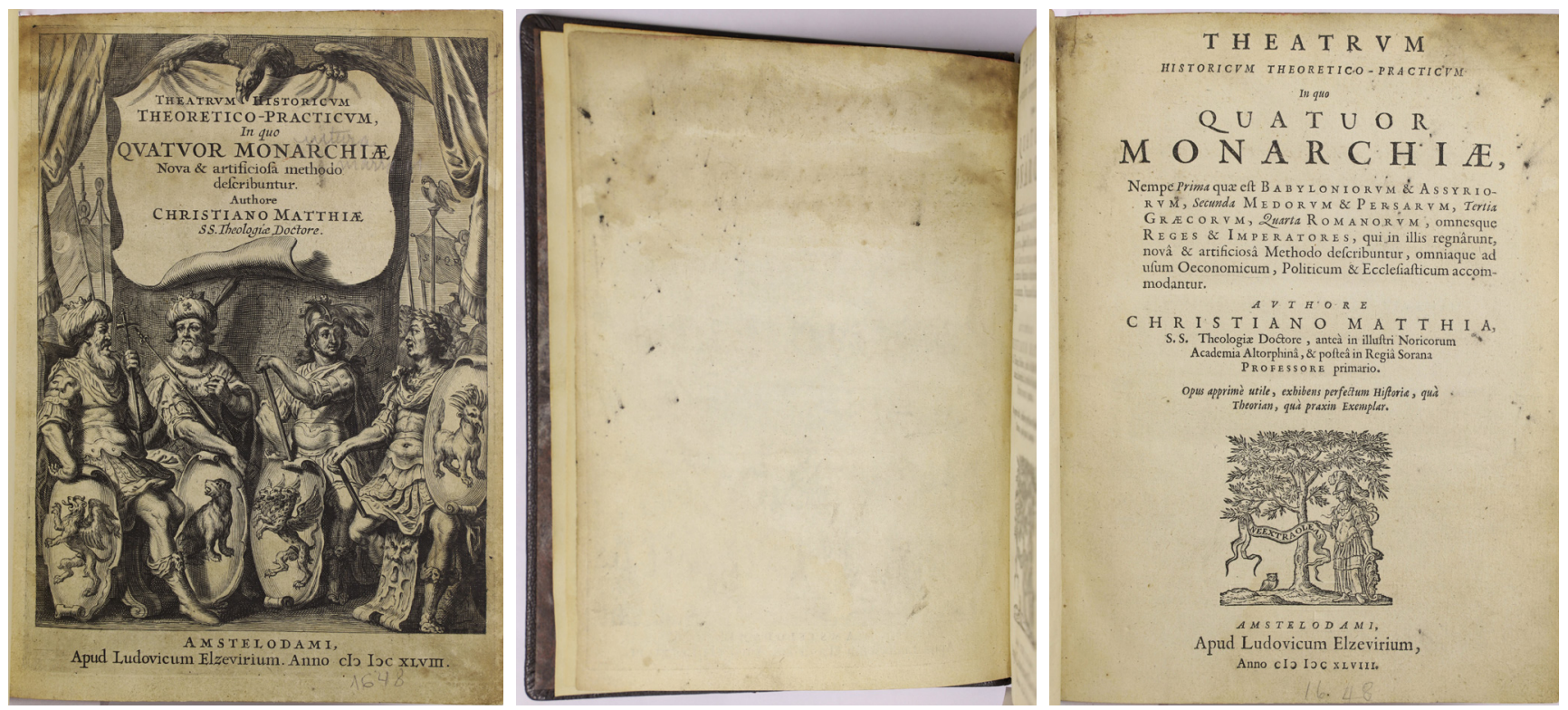

Figura 15 - Frontispício e folha de rosto da obra: Mattiae (1648). Acervo da Biblioteca Central da Universidade de Brasília. 
Tanto nas páginas internas de uma obra quanto em sua folha de rosto ou no frontispício, pode-se distinguir dois processos de produção de gravuras mais frequentes no período, a saber: imagens impressas ora em relevo, ora a entalhe (intaglio). Ainda que imagens em relevo pudessem ser gravadas em metal, como fizera Jakob Faber a partir dos desenhos de Hans Holbein na década de 1520, a técnica mais recorrente de produção de gravuras em relevo entre os séculos XV e XVIII é a xilogravura. Nesse caso, as mãos do artista extraem do bloco de madeira a região que não deve figurar na imagem impressa, deixando, em relevo, apenas os traços da imagem invertida que receberão a tinta, como em um carimbo. Trata-se, portanto, do mesmo princípio de impressão de textos com tipos móveis, motivo pelo qual as matrizes xilográficas eram inseridas com facilidade nas páginas compostas na oficina de impressão. Uma vez nivelado, todo o conjunto poderia receber a tinta e ser levado à prensa de uma só vez.

Reconhece-se uma gravura impressa em relevo sobretudo pelo relevo deixado pela matriz em madeira ou metal na região da mancha impressa e pelo comportamento da tinta no papel. As reproduções ampliadas na Figura 16 ilustram essas características. Em primeiro lugar, destaca-se o relevo deixado no papel na região impressa em função da ação da prensa no momento da impressão. $\bigcirc$ suporte flexível de papel absorve a pressão aplicada com o auxílio da prensa, de modo que o verso de uma gravura impressa em relevo frequentemente apresenta elevações coincidentes com as linhas registradas no recto, como destacado na imagem localizada no canto inferior direito da Figura 16. Da ação da prensa ainda decorre, em segundo lugar, que a tinta viscosa tende a se acumular no papel nas extremidades das linhas impressas, algo que se constata mais claramente por meio de ampliações óticas. Trata-se do resultado gráfico decorrente do efeito mecânico de deslocamento lateral da tinta. Efeito semelhante ocorreria se pressionássemos, com um dedo, uma camada inicialmente uniforme de pasta de dente previamente disposta em uma superfície plana. Note-se que esse efeito se verifica apenas nos algarismos romanos impressos na oficina de Cratander em 1526, e não nas letras posteriormente adicionadas à mão para se registrar o ano de 1538 na folha de rosto do exemplar preservado na Biblioteca Central da Universidade de Brasília (cf. Figura 4). 


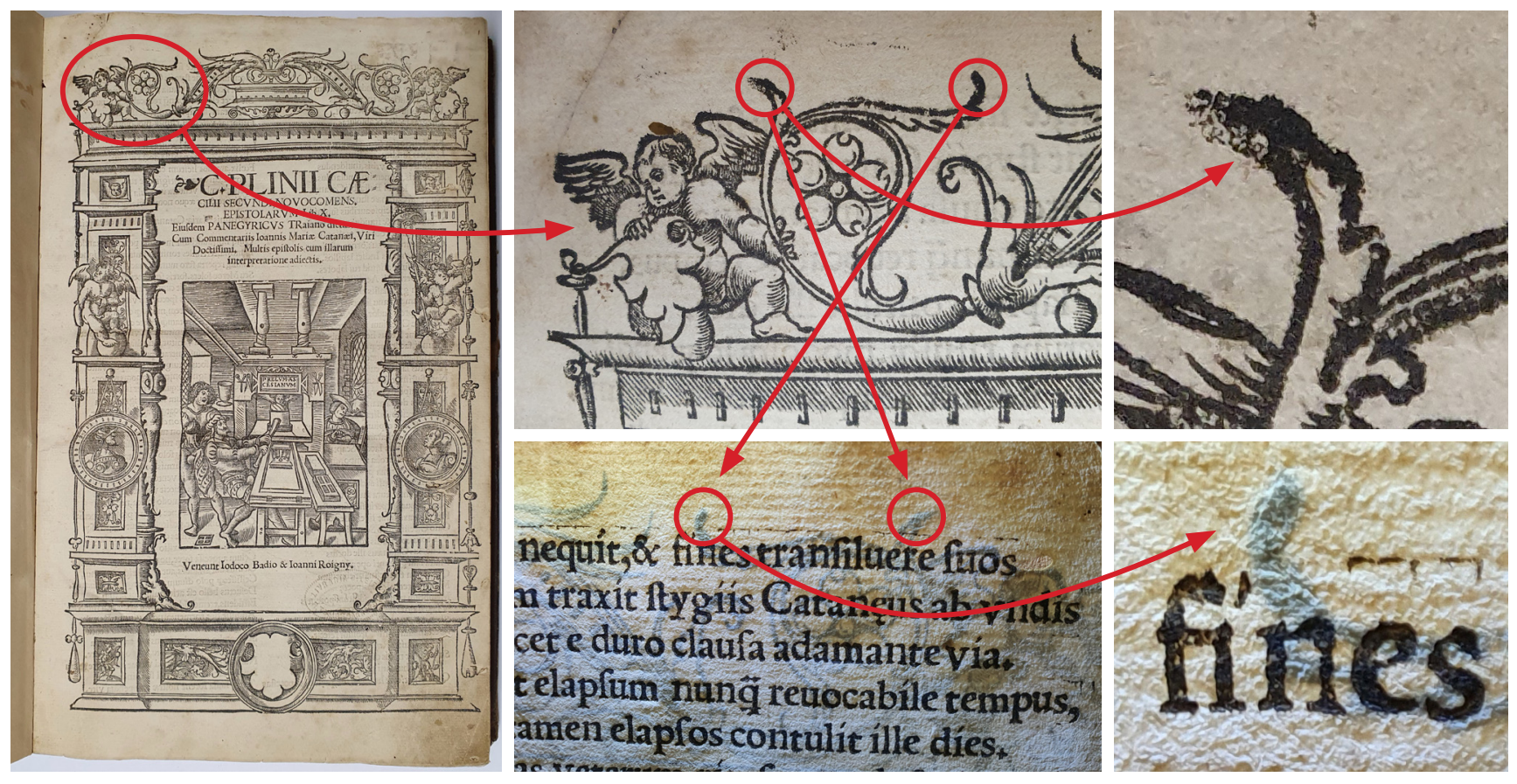

Figura 16 - Gravura em relevo na folha de rosto de uma edição quinhentista das cartas de Plínio, o Jovem. Plínio Cecílio Segundo (1533). Acervo da Biblioteca Central da Universidade de Brasília.

Mas nem todas as imagens impressas no período resultam da ação da prensa tipográfica. Também gravuras entalhadas no metal - a entalhe - ganham espaço já no século XV, ainda que passem a ser utilizadas mais frequentemente como ilustração de livros sobretudo a partir do século XVII. Nesse caso, artistas produzem sulcos em uma chapa metálica, mais tradicionalmente de cobre. Os sulcos resultam ora diretamente da ação mecânica de um instrumento denominado buril, por meio do qual gravam-se as incisões no metal, ora da ação química de uma substância ácida. Essa última técnica consiste em cobrir inicialmente a chapa metálica com cera ou resina. Com a ajuda de outro instrumento pontiagudo, artistas desenhavam à mão livre no metal, de forma que as linhas traçadas não ficassem mais protegidas pela cera ou resina. Ao entrar em contato com o ácido, apenas as partes expostas do metal sofriam a corrosão, deixando as regiões cobertas pela cera ou resina livres do desgaste. Como resultado, tem-se que os efeitos artísticos e estéticos alcançados pelas duas técnicas, frequentemente conjugadas na calcogravura, são distintos daqueles atingidos pela gravura em relevo, sendo mais fácil produzir alterações de tom e regiões de sombreamento nas gravuras entalhadas no metal. Em função das diferentes etapas de produção dessas gravuras, diversos agentes encontram-se por vezes identificados na imagem, mais comumente por meio de uma terminologia latina. Designa-se com a expressão regularmente 
abreviada del. (delineavit) aquele ou aquela que desenhou a cena, independentemente do suporte, enquanto que as mãos que operaram o buril são identificadas pelo termo igualmente abreviado sculp. (sculpsit).

Já que os traços a serem reproduzidos no papel são mais profundos do que a superfície da chapa metálica, não é possível imprimir gravuras a entalho com a prensa de tipos móveis, destinada a reproduzir formas gravadas em relevo. Nas gravuras em metal, a tinta, um pouco mais fluida do que aquela utilizada na operação da prensa tipográfica, é espalhada na chapa metálica de modo a preencher os sulcos abertos pelo buril ou pelo ácido. Após retirar manualmente o excesso de tinta depositado na superfície, deixando-a acumulada apenas nos sulcos, a chapa metálica é levada à prensa calcográfica, que exerce maior pressão no suporte por meio da ação de dois cilindros. Antes de passar pela prensa, a folha de papel suficientemente umedecida é colocada por cima da chapa metálica, a que se segue uma folha de feltro ou material similar. A pressão sofrida pelo conjunto é parcialmente impulsionada pela maleabilidade do feltro para dentro dos sulcos da chapa metálica, com o objetivo de ajudar a absorção da tinta pelo papel.

Como no caso das gravuras em relevo, também aqui pode-se reconhecer uma gravura a entalho por meio do relevo deixado no papel pela matriz metálica, pela forma dos traços impressos e pelo comportamento da tinta no papel. Uma vez que as gravuras em metal requerem maior pressão para transferir a imagem e que os traços reproduzidos se encontram abaixo da superfície da matriz, são, portanto, as bordas da chapa metálica - e não o relevo da imagem ou dos caracteres - que deixam marcas salientes no papel. Esse relevo é denominado testemunho e se encontra sinalizado por meio das setas azuis inseridas na primeira imagem da Figura 17. Em alguns casos, no entanto, o testemunho pode eventualmente ter sido eliminado pelo corte do papel operado pelo encadernador, por exemplo. Quanto à forma dos traços impressos, note-se nas imagens ampliadas na Figura 17 como as extremidades das linhas abertas pelo buril reproduzem a entrada pontiaguda do instrumento no metal. Esse processo, denominado talho-doce, é mais dispendioso do ponto de vista econômico do que o processo com ácido, denominado água-forte. Neste último caso, as linhas desgastadas pela corrosão ocasionada pelo ácido na superfície metálica apresentam, quando impressas, extremidades mais arredondadas. E uma vez que a tinta se acumula nos sulcos da chapa metálica independentemente da técnica adotada, a impressão não apresenta regiões de acúmulo de tinta que resultaria do efeito mecânico de seu deslocamento lateral. 

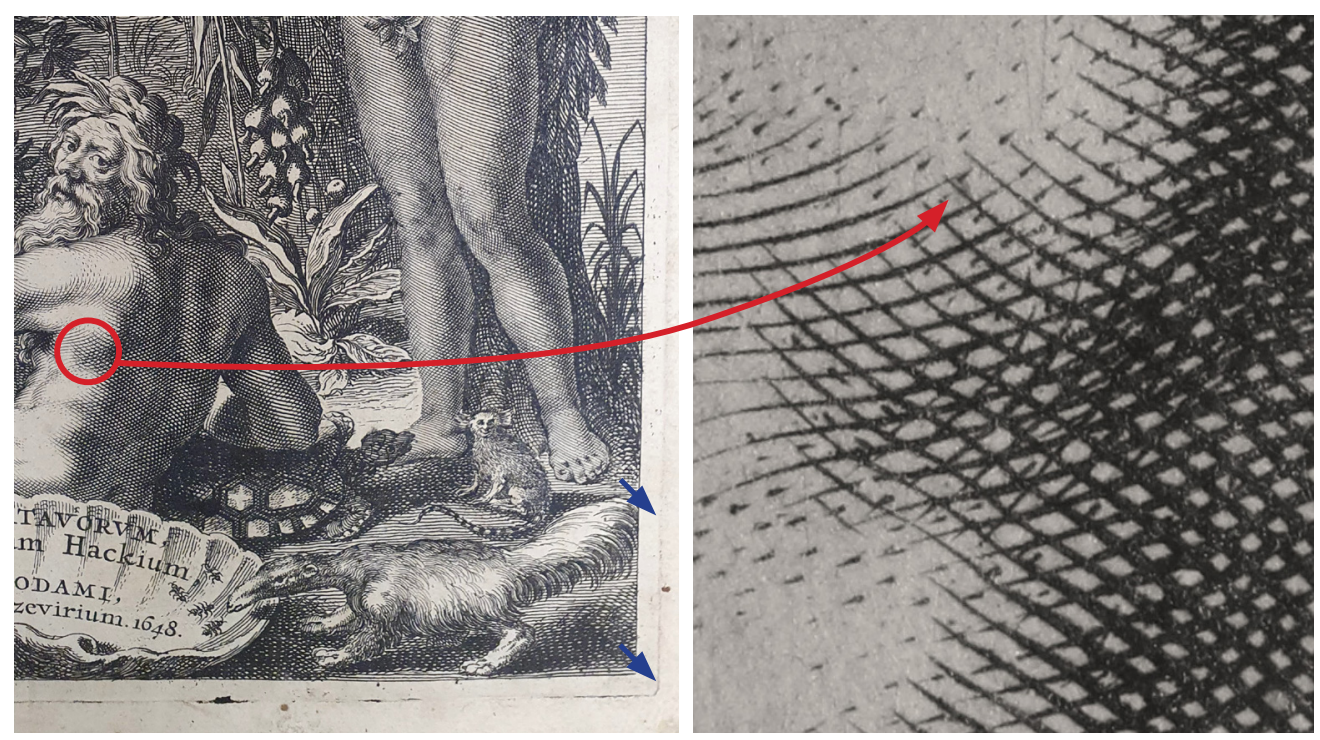

Figura 17 - Detalhe de gravura em metal. Frontispício da obra: Piso (1648). Acervo da Biblioteca Central da Universidade de Brasília.

$\bigcirc$ excesso de tinta na superfície que não deve ser impressa é retirado, sendo este um trabalho árduo e nem sempre executado com perfeição, muitas vezes deixando regiões acinzentadas na mancha impressa, algo que ocorre com mais frequência sobretudo nas obras de menor custo e produzidas mais rapidamente. Assim, o resultado final do produto manufaturado revela, em suas características gráficas e materiais, elementos que permitem fazer considerações iniciais sobre a produção e o consumo da obra impressa, que por sua vez devem ser confirmadas por meio de outros vestígios históricos. Já o papel, agora fornecido pelo impressor que opera a prensa calcográfica - e não mais pelo editor da obra impressa com tipos móveis -, tem possivelmente proveniência distinta daquele utilizado para imprimir os cadernos de texto. No caso em que volumes tipografados deveriam ser acompanhados por pranchas com ilustrações avulsas, elas eram posteriormente adicionadas à obra por ocasião da encadernação, razão pela qual os gravadores frequentemente indicavam na chapa metálica a posição na qual a imagem produzida para este fim deveria ser inserida. Quando as expectativas de completude das peças eram contrariadas, leitores, encadernadores e livreiros registravam a ausência das pranchas com imagens em correspondências destinadas aos impressores e editores do título. ${ }^{42}$ Também ocorre que gravuras em metal são impressas nos espaços livres deixados pela oficina de impressão na página previamente tipografada. Essa sequência de produção do trabalho coletivo de que resultam os artefatos impressos se justifica em função do custo mais elevado das imagens a entalho. 
43. Cf. Hedges (2006).

44. Para análises concretas da reutilização de matrizes de gravuras em relevo na Época Moderna, cf. Araújo (2020b, p. 28-30); Kusukawa (2012, p. 118).
Pesquisas recentes apresentam métodos para datar impressos do início da Época Moderna a partir da análise gráfica e material das imagens. Uma vez que muitas obras e gravuras não se encontram datadas, evidências bibliográficas apresentadas exclusivamente pelo papel e pela marca d'água nem sempre fornecem dados suficientes para assegurar uma datação mais precisa. Por esse motivo, são conhecidos usos da evidência de que as matrizes de madeira e metal utilizadas para gravar imagens em relevo ou a entalho, respectivamente, deterioramse a uma taxa constante. Parte-se da constatação que a pressão exercida pela prensa tipográfica nos blocos de madeira ocasiona pequenas quebras e fissuras no material que se evidenciam nas imagens gravadas. De modo análogo, a pressão mais intensa na chapa das gravuras em metal causa leve desgaste mecânico da superfície do cobre, aplainando os sulcos. ${ }^{43}$ Como consequência, tem-se que as linhas de impressões mais tardias da mesma matriz, eventualmente desgastadas pelo uso, originam-se do acúmulo de tinta em sulcos mais rasos na chapa, de forma a apresentar, no papel impresso, um resultado gráfico mais delgado. E sobretudo em função dos custos envolvidos na operação coletiva levada adiante por editores, artistas, gravadores e impressores, constantes são as reutilizações e o comércio de matrizes de gravuras em relevo e a entalho, ${ }^{44}$ como é o caso da cercadura utilizada em prensas distintas da Basileia na década de 1520 e que se desloca posteriormente para ornamentar os produtos de uma oficina de impressão em Lyon. Ao seguir essa trilha, a pesquisa histórica passa a enxergar nos artefatos impressos vestígios reveladores da organização social do trabalho, das estratégias econômicas de produção e das conexões estabelecidas por meio da circulação da informação na Época Moderna.

\section{SINGULARIDADE E VARIAÇÕES DOS PRODUTOS DA PRENSA MANUAL}

Ao longo do primeiro século de operação da prensa, as informações de produção dos tífulos foram deslocadas do colofão - próprio sobretudo aos livros manuscritos - para a folha de rosto, como verificado na edição do Corpus Hippocraticum preservada na Biblioteca Central da Universidade de Brasília. Na porção central e inferior da folha inicial, localiza-se frequentemente um bloco de texto denominado imprenta, cuja função é identificar o editor e/ou o impressor, o local e a data de impressão do título, e possivelmente ainda apresentar informações relacionadas à venda do produto manufaturado. Foi na imprenta do exemplar brasiliense levado à prensa por Cratander em 1526 que a data sofreu alteração. 
Assim, o valor de face das informações registradas na folha de rosto pode não ser inteiramente confiável - e não apenas por conta de eventuais modificações adicionadas posterior e manualmente às peças. Ocorre que tipógrafos e impressores com frequência compunham deliberadamente folhas de rosto com informações falsas, sobretudo por conta da ação da censura, do sistema de concessão de privilégios de impressão, assim como também de estratégias comerciais que impulsionavam as vendas de edições mais recentes de obras demandadas pelo público letrado. ${ }^{45}$ Casos conhecidos decorrem da atuação de genebrinos protestantes que, para manter suas prensas em atividade, informaram endereços falsos nas folhas de rosto de obras destinadas às regiões de confissão católica. ${ }^{46}$

Entretanto, conhecer o local no qual uma obra foi declaradamente produzida e as instituições que dela contemporaneamente abrigam um ou mais exemplares informa-nos apenas uma parte da trajetória do artefato impresso. Recorrentes são os casos em que as peças preservadas revelam, ao mesmo tempo que escondem, outras evidências de proveniência. Exemplos de supressão da informação ocorrem quando traços de propriedade são destruídos intencionalmente em caso de furto ${ }^{47}$ - com o objetivo de eliminar eventuais marcas identificadoras de um exemplar em particular -, ou por preferência de novos colecionadores. Também pode ocorrer perda de informação relativa à história de um exemplar por ocasião da inclusão de uma nova encadernação ou de ações pouco cautelosas de restauração das peças. ${ }^{48}$ Ao se considerar, portanto, marcas de proveniência deixadas em artefatos impressos à época da prensa manual, vejamos o caso de outra obra que faz parte do acervo da Biblioteca Central da Universidade de Brasília. Nela, a informação registrada com tinta ferrogálica de base aquosa amplia o valor histórico do exemplar frente às informações estampadas no papel pela ação da prensa.

exemplar brasiliense da coleção de viagens datada de 1651 e difundida sob o título Relations veritables et curieuses de l'isle de Madagascar, et du Bresil expõe, na margem superior da folha de rosto, a seguinte informação manuscrita, em forma caligráfica compatível com a escrita setecentista: Bibliothecae Colbertinae. A informação diz respeito à vasta e importante coleção de obras impressas e manuscritas de Jean-Baptiste Colbert (1619-1683), controlador geral das finanças francesas à época do reinado de Luís XIV. O termo aparece registrado em forma caligráfica também compatível com as variações manuscritas da mesma expressão registrada em outros impressos atualmente preservados em diversas instituições e conhecidamente oriundos da biblioteca de Colbert, que em 24 de maio de 1728 foi a leilão em Paris. Para esta ocasião, produziu-se um catálogo no qual a obra de 1651 se encontra listada. ${ }^{49}$ Essa
45. Araújo (2020b, p. 8).

46. Febvre; Martin (2017, p. 285).

47. Sobre o registro de informações que particularizam um exemplar tendo em vista o combate ao furto de bens patrimoniais, consulte-se: Greenhalgh (2014, p. 111-112).

48. Pearson (2019, p. 7-14). Para um projeto de pesquisa mais recente relativo às marcas proveniência em acervos brasileiros, consulte-se: Azevedo (2020).

49. Bibliotheca Colbertina (1728, p. 676). 
50. ARAÚJO, André de Melo; BEZZI, Marina. Relations veritables et cvrievses de l'isle de Madagascar, et dv Bresil. In: ARAÚJO, André de Melo; LOURENÇO, Néria; GREENHALGH, Raphael Diego (eds.). Obras raras da Biblioteca Central da Universidade de Brasília: séculos XVI e XVII. Brasília, DF: Editora Universidade de Brasília, 2021. No prelo. última informação impressa fortalece a hipótese de atribuição de propriedade do exemplar a Colbert, como evidenciado no registro manuscrito exposto na folha de rosto reproduzida na Figura 18. Nela, pode-se reconhecer as marcas de proveniência do exemplar brasiliense, ao mesmo tempo que se evidenciam de forma ampliada as diferenças de comportamento das tintas de base aquosa e oleosa depositadas no papel seiscentista. Ainda que a indicação de provável proveniência do exemplar encontre-se ałualmente amparada apenas no registro manuscrito e no catálogo impresso no século XVIII - uma vez que se desconhecem evidências complementares de compra-, o valor de mercado comparativamente baixo do título do qual diversos exemplares originais são conhecidos faz da informação manuscrita presente na folha de rosto improvável candidata à ação de falsificadores. Certo é que leituras dessa ordem alimentaram o contexto intelectual e político de criação da Compagnie française des Indes occidentales (Companhia das Índias Ocidentais) em 1664 pelo próprio Colbert. ${ }^{50}$ Por outro lado, pelas características mais contemporâneas da atual meia encadernação em couro marrom que protege o exemplar brasiliense, ela pode ter substituído - e, portanto, descartado - uma encadernação brasonada em marroquim (couro de cabra) vermelho decorado com fios dourados e monograma "JBC" na lombada, característica de parte dos exemplares da biblioteca colbertina. De todo modo, marcas de proveniência singularizam os artefatos impressos.

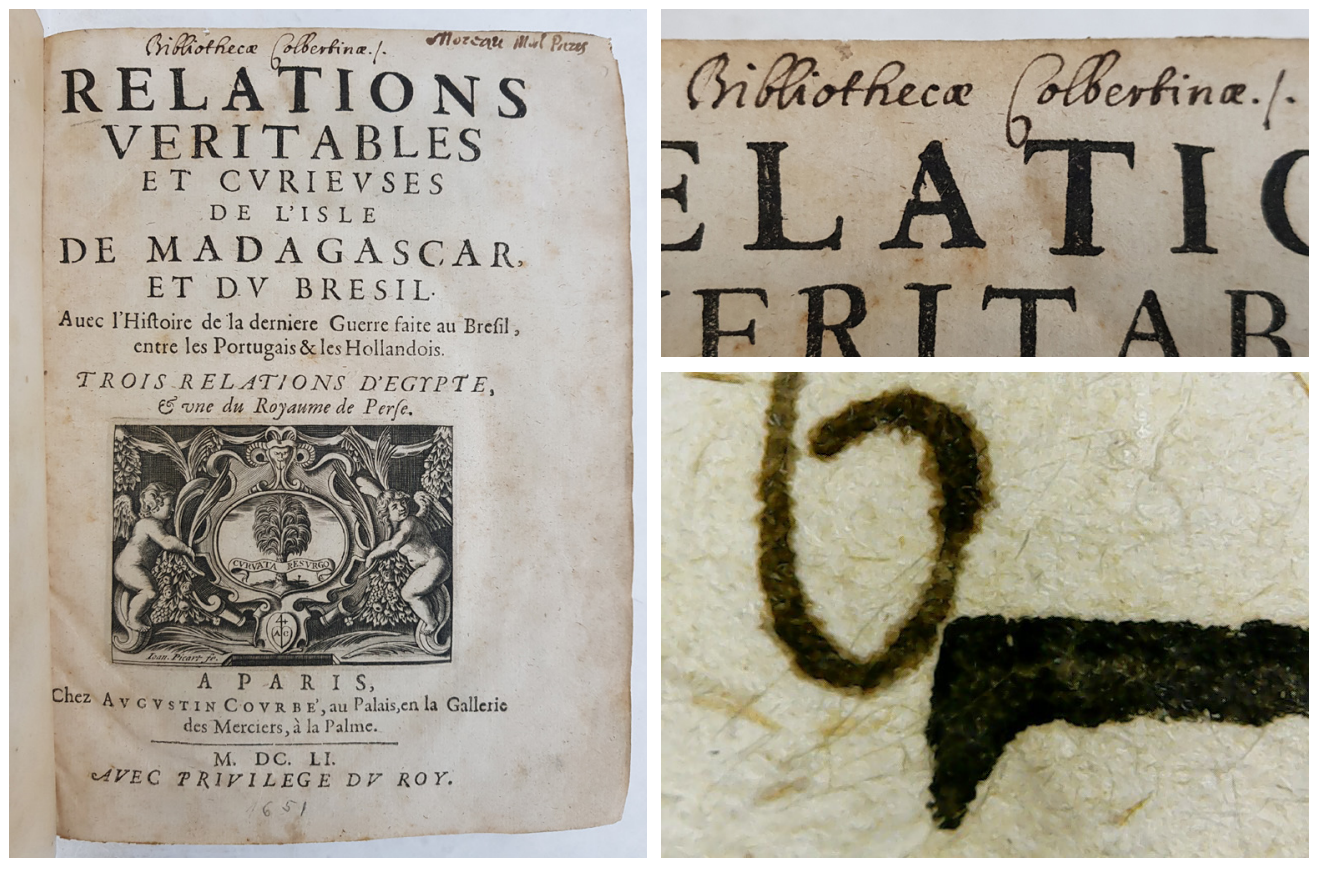

Figura 18 - Folha de rosto da obra Relations veritables et cvrievses (1651). Acervo da Biblioteca Central da Universidade de Brasília. 
O exemplar da obra Relations veritables preservado na Universidade de Brasília exibe uma gravura em metal não apenas na folha de rosto, mas também em uma prancha acrescida aos cadernos de texto. No caso da prancha, trata-se de um mapa da llha de Madagascar impresso em papel levemente mais claro e com marca d'água distinta daquela presente nas outras folhas do volume. A gravura se encontra inserida entre o índice e a primeira página do texto principal. Uma vez que partes integrantes de um título impresso eram frequentemente ordenadas e unidas por encadernadores e livreiros, gravadores e impressores preocupavam-se em deixar sinais gráficos ora nas páginas compostas tipograficamente, ora nas pranchas que resultam do trabalho executado por meio da prensa calcográfica. Trata-se de sinais destinados a orientar o trabalho de produção e finalização das peças impressas. Todavia, note-se que, no caso do mapa de Madagascar encadernado entre os cadernos de texto da obra Relations veritables e identificado pela expressão "Fol. I" no canto superior direito da imagem, a Biblioteca Nacional da França preserva a mesma gravura na forma de material avulso, por sua vez oriundo da coleção de documentos cartográficos da Época Moderna constituída pelo geógrafo e cartógrafo francês Jean-Baptiste Bourguignon D'Anville. ${ }^{51}$ As duas formas contemporâneas de catalogação e preservação de cópias distintas de uma imagem impressa a partir da mesma matriz metálica comprovam que as gravuras produzidas no período eram comercializadas e consumidas de diversos modos.

Nas páginas tipografadas, os sinais destinados aos encadernadores e livreiros encontram-se bem estruturados. Denomina-se reclamo a palavra - ou parte dela - localizada no canto inferior direito da mancha impressa, palavra esta que corresponde ao primeiro vocábulo impresso na página seguinte, de forma a dar continuidade ao fluxo da leitura. Os reclamos têm por objetivo sinalizar para encadernadores e livreiros a sequência correta das páginas impressas e, consequentemente, dos cadernos de texto. Outros sinais gráficos deixados pelos impressores na página com o objetivo de facilitar a integração posterior das partes de um livro são as assinaturas. Denominam-se assinaturas as letras, frequentemente seguidas de números arábicos ou romanos e localizadas mais ao centro da porção inferior da página impressa na mesma linha dos reclamos, como indicado na Figura 19.
51. Cf. BIBLIOTHÈQUE nationale de France. GE DD2987 (8359), Número de identificação: ark:/12148/ btv1b8595711j. Département Cartes et Plans, Paris, 2020. Disponível em: $<$ https://bit.1y/31BgkGT>. Acesso em: 1 nov. 2020. 


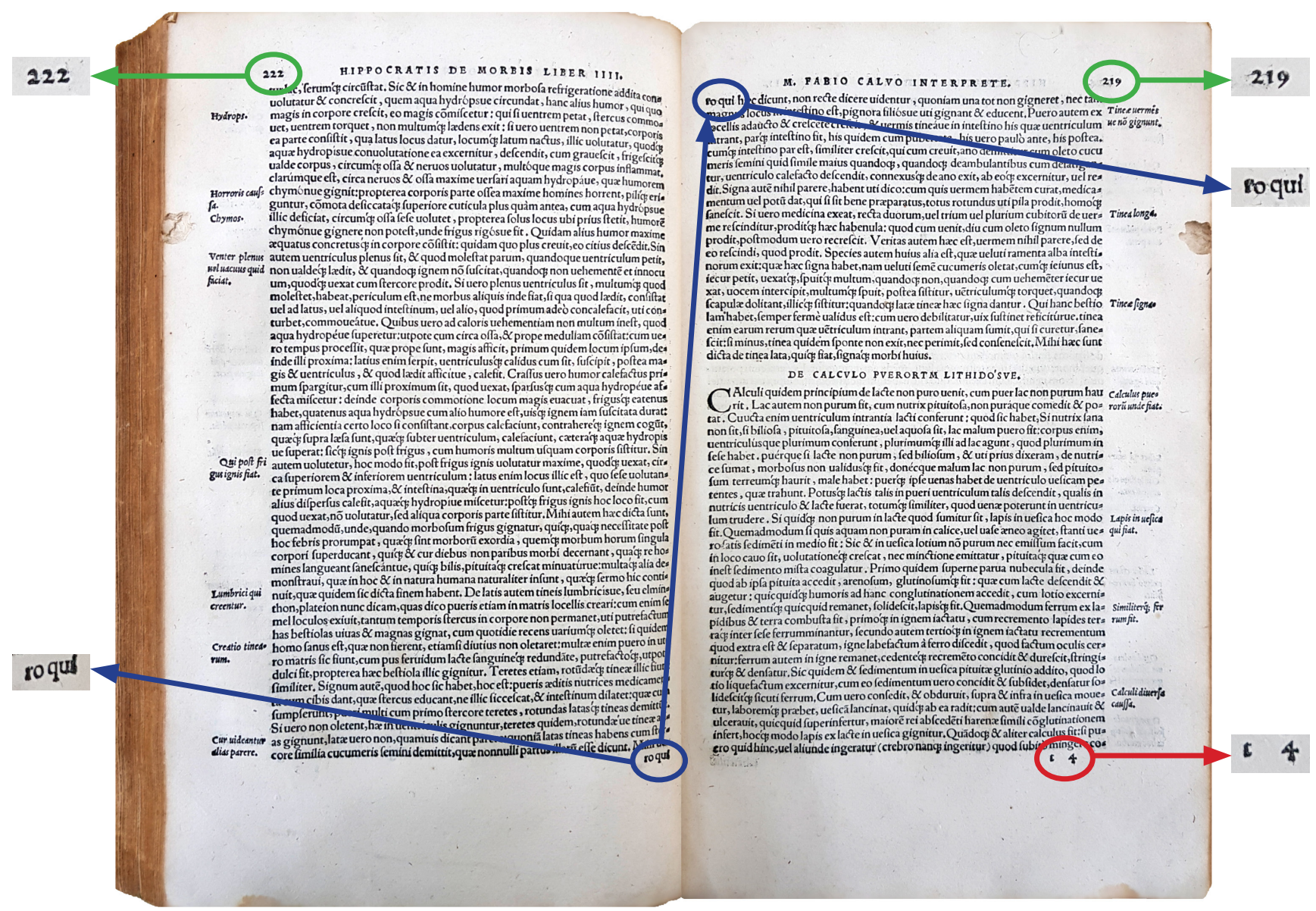

Figura 19 - Numeração das páginas (em verde), com erro sequencial característico da edição de Cratander de 1526 do Corpus Hippocraticum, assinatura (em vermelho) e reclamo (em azul). Hippocratis coi medicorvm omnivm (1526). Acervo da Biblioteca Central da Universidade de Brasília.

As letras integrantes das assinaturas designam um caderno de texto em particular, de modo que um caderno de texto composto de dezesseis páginas impressas - como é o caso frequente de uma obra in-octavo - recebe a indicação A 1 ou Ai na primeira página, A2 ou Aij na terceira, A3 ou Aiij na quinta e A4 ou Aiiij na sétima. Trata-se do caderno A, composto de dezesseis páginas. Note-se que não há necessidade de indicar a sequência das outras páginas que integram o mesmo caderno, uma vez que o verso de uma página não pode se desencontrar da sequência de seu recto, e que as páginas 1, 2, 15 e 16 -assim como também é o caso das páginas 3,4, 13 e 14; 5, 6, 11 e 12; 7, 8, 9 e 10 - encontram-se materialmente unidas, como ilustrado na Figura 20, que apresenta um esquema de imposição frequente à época da prensa manual. 


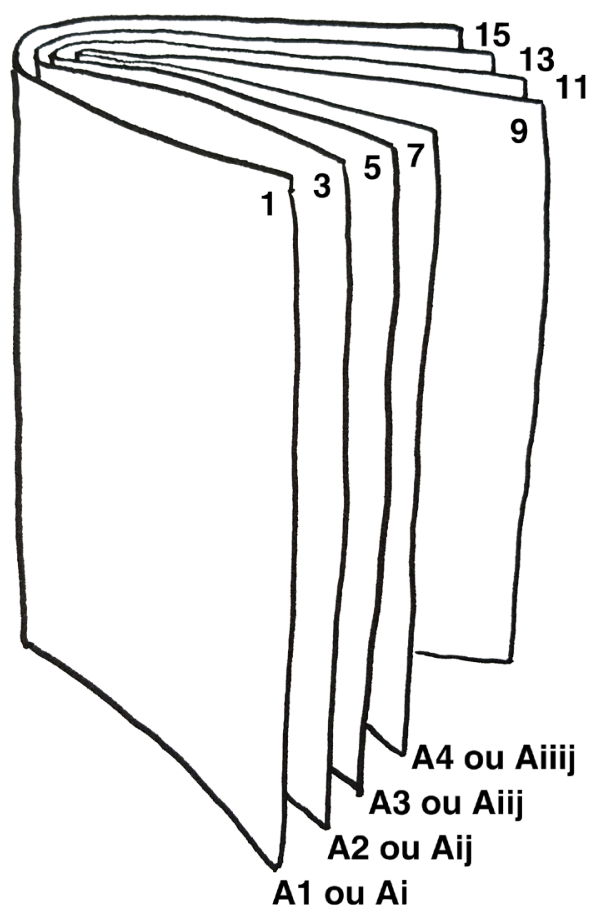

Figura 20 - Caderno A.

Veja-se também que, no exemplo ilustrado na Figura 20, o número 1 pode se encontrar grafado em algarismo romano, identificado pela letra "i", com a particularidade de que a última letra da sequência é frequentemente substituída pelo caractere "i". De fato, em impressos do período percebe-se a substituição constante entre os caracteres I e J, U e V, frequentemente utilizados de forma intercambiável em diversas línguas. Esse é o caso da forma de registro do substantivo próprio Jakob no monograma IF, de Jakob Faber, presente na gravura utilizada nas prensas de Curio, Cratander e Bebel na Basileia. Disso resulta que no caso das letras designadoras das assinaturas os caracteres J, U e W não são utilizados, de modo que o alfabeto completo apresenta 23 (e não 26!) possibilidades de sequenciamento dos cadernos de texto. No caso de obras extensas, o sequenciamento alfabético é continuado pelo registro duplicado das letras. Assim, a assinatura Z8 laqui forçosamente explicitada apenas com finalidade didática, uma vez que apenas a assinatura Z4 aparece graficamente registrada na página impressa) é seguida das assinaturas $A A 1, B B 1, C C 1$ e assim por diante, repetindo as letras do alfabeto ao final de uma sequência completa por duas, três, quatro ou mais vezes. Também no(s) primeiro(s) cadernos de uma obra impressa, frequentemente levados por último à prensa, uma vez que nele(s) se encontra(m) os elementos paratextuais - tais como folha de rosto, 
52. Cf. Sawyer (2019).

53. Faria; Pericão (2008, p. 175).

54. Nesse caso particular, trata-se de uma obra in-octavo, mas com dimensões reduzidas. Cf. Piamontes (1691). dedicatórias e prefácios -, é comum o uso de letras do alfabeto grego $(\alpha)$, caracteres acentuados (ã), ou caracteres especiais - tais como: $*, \dagger, 1:(,-$ para indicar a assinatura do(s) caderno(s) que antecede(m) a sequência regular dos cadernos que contêm o texto principal.

As assinaturas fornecem evidência bibliográfica do ordenamento planejado nas oficinas de impressão dos cadernos de texto que integram uma obra, de modo que lacunas verificadas no sequenciamento das assinaturas podem eventualmente indicar perda ou supressão de material impresso. ${ }^{52}$ Nesse sentido, colacionar é o ato de "verificar, através das assinaturas dos cadernos, do exame das páginas, folhas e ilustrações se uma espécie bibliográfica está ou não completa e perfeita." Assim, a colação revela a "[...] organização dos cadernos impressos de acordo com a sucessão das suas assinaturas." ${ }^{23}$

Enquanto as assinaturas orientavam o trabalho de encadernadores e livreiros na Época Moderna, o registro contemporâneo da colação de um exemplar pode permitir comparação com outros exemplares preservados do mesmo título, ao evidenciar eventuais singularidades entre os artefatos impressos preservados em distintas coleções. Desse modo, por extensão, colacionar também indica a ação de comparar a descrição física de mais de um exemplar de uma mesma obra, com o objetivo de identificar variações ou uniformidades entre elas. Diversas bibliotecas registram em seus catálogos, por meio de uma fórmula colacional, o formato de uma obra, a sequência de suas assinaturas, além do número de folhas numeradas e sem numeração. Trata-se de informação importante para a pesquisa histórica por meio da qual se pode compreender as características particulares do exemplar estudado e compará-las com aquelas de exemplares distintos do mesmo título, por sua vez catalogados em outra instituição.

Um exemplo de colação simples é aquela feita a partir do exemplar preservado na Biblioteca Central da Universidade de Brasília da obra Secretos del Reverendo Don Alexo Piamontes (1691): $8^{\circ}: \pi^{4}, A-Z^{8}, 2 A-2 O^{8}$. Trata-se de uma obra in-octavo, aqui sinalizado pela informação " $8^{\circ},{ }^{54}$ diferentemente da notação convencionada para obras impressas nos formatos in-quarto $\left(4^{\circ}\right)$ ou infolio $\left(2^{\circ}\right)$. $\bigcirc$ exemplar apresenta inicialmente um caderno de texto com páginas preliminares impressas em meia folha de papel com a assinatura " $\pi$ ", com oito faces integral ou parcialmente impressas, a saber: $\pi 1$ recto, $\pi 1$ verso, $\pi 2$ recto, $\pi 2$ verso, $\pi 3$ recto, $\pi 3$ verso, $\pi 4$ recto e $\pi 4$ verso. Trata-se seguramente de meia folha de papel, iá que o formato in-octavo dá à folha de papel dezesseis páginas de impressão. A essas páginas iniciais sucedem-se 23 cadernos de texto, identificados com as letras de $A$ a $Z$, excetuando-se as letras J, $U$ e W, com dezesseis páginas cada. Posteriormente, seguem-se catorze cadernos de texto, 
identificados com as letras duplicadas de A a $O$, excetuando-se a letra J, igualmente com dezesseis páginas cada. ${ }^{55}$

Uma vez que a função precípua da assinatura no momento de produção do artefato impresso era indicar a ordenação dos cadernos de texto, os compositores dispunham-na de modo relativamente arbitrário, desde que localizada na porção inferior central da página. Assim, nessa linha suplementar adicionada pelo compositor de tipos móveis à mancha ocupada pelo texto principal constam apenas a assinatura e o reclamo. Por meio da análise do posicionamento da assinatura, pode-se identificar variações entre diferentes edições de um mesmo título. Tais variações operadas entre os séculos XVI e XVII não encontram representação no acervo de obras raras da Biblioteca Central da Universidade de Brasília. No entanto, o caso do título reproduzido na Figura 21 , que circulou em distintas edições impressas nesse período, é paradigmático. Trata-se da obra A goldlie forme of hovseholde government, impressa em 1598 por Felix Kingston para o editor Thomas Man. ${ }^{56}$ Uma segunda edição da mesma obra, cuja data de impressão informada na folha de rosto é 1600, procura emular a composição do texto da edição anterior. Note-se que tanto a primeira quanto a última palavra impressa na página 135 é a mesma. Como a fôrma levada à prensa era recomposta ao final da impressão das cópias previamente planejadas de uma página - para reutilizar os tipos móveis em outros cadernos do mesmo título, ou ainda em outro trabalho em produção paralela na mesma oficina de impressão -, novas edições à época da prensa manual exigiam renovado trabalho do compositor. Adicionalmente, pequenas variações entre o texto das edições de 1598 e 1600 levaram à reorganização da quebra das linhas, como é o caso, no exemplo reproduzido na Figura 21 , da terceira linha do bloco de texto principal. De todo modo, o compositor procurava ser fiel à composição da página e à economia de produção da obra original. Mas eis que em 1603 Thomas Man encomenda a impressão do título a Thomas Creede, segundo a informação registrada na imprenta. Ainda que fosse frequente na Época Moderna que exemplares encalhados da venda de uma obra passassem a ser comercializados com uma nova folha de rosto, não raro composta com data atualizada para sinalizar a novidade do produto colocado à venda, esse não é o caso das obras aqui reproduzidas.
55. Para casos mais complexos e para aprofundar o conhecimento sobre a fórmula colacional, consulte-se: Bowes (2012, p. 193-254); Gaskell (2012, p. 328-335).

56. A goldlie forme of hovsebolde government (1598). 


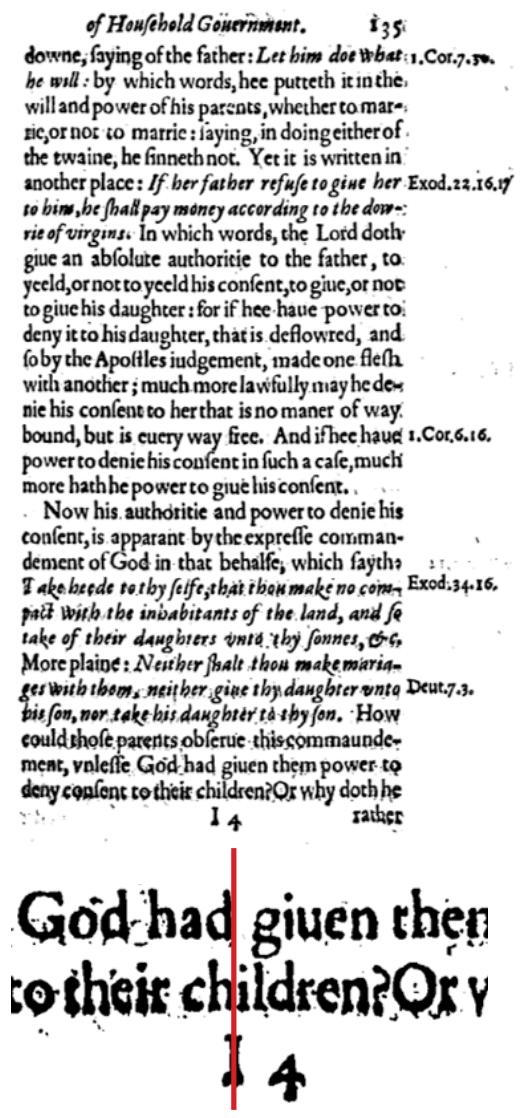

of Howfebold Gouernment.

$\times 35$ downe, faying of the father: Let bim dowbat 1.Cor.7.36 bewill. By which words, he putteth it in the we will and power of the father, either to beftow or not tobeftow his daughter in marriaye; faying in doing cither of the twaine, bee simeth not. Yet it is writeen in another place : If ber Exod.22.16. not. Yet it is writece ber io bim, he phall pay money according to the dowrie of Virgins. In which words, the Lord doth give an ablolute authoritie to thefather, to yeeld, or not to yceld his confent, to giue, or not to giue his daughter. For if fent, to giue, or not to giue his daughter. For is deflowred,\& 10 , by the Apoltles iudgement, made one flefh with another; much more lawfully ma hee deny his confent to her that is no maner of way bound, but is euery way free. And if 1 . Cor. 6,16 . he haue power to deny his cöfent in fuch a cafe, much more hath he power to giue his confent.

Now his authoritie and power to deny his consent, is apparane by the expreffec commanconfent, is apparant by the expreffe commandement of God in that behalfe, which rayth:
Take beede to thy felfe, that thou make no com- Exod.34.16. pad wish the inbabisants of the land, and fo take of therr daughters vnto thy fonves, ofc. Mose plaine : Neyther Balt ihou make marriages Deut.7.3. with thems, seither gise thy daughter vnto bis fonse, nor take bis daugbter to thy fonme. How could thole parents oblerue this commaundepent, vnleffe God had giuen them powerto pent, vnlefte God had given them why doth he

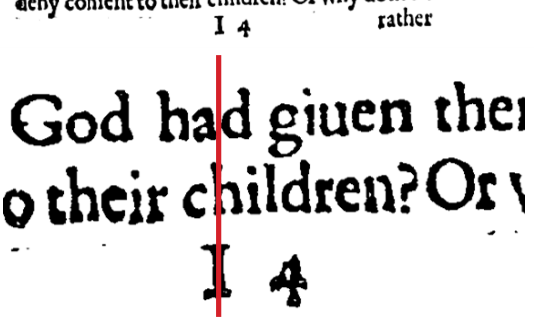

of Hoiffehold Gonernment. iss

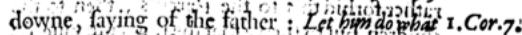
bee will By which wordes he puttethit mo the 36 . will and power of the fither, erther to bef tow or not to beftow his daughter in marriage; f ay. ing, in doing either of the twaine bee fwine

not Yet it is written in an other place ; If Ger Exod.22.

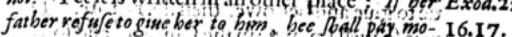

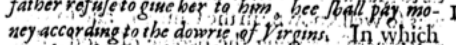
words, the $\mathrm{L}$ orde doth onic on abfolute aut hó rity tathe father to yecld, or not to yeeld this con fent to giue, or not to giuchis diughter. Fol if he haue powver to denie it to his daughtiter that he haue pgyver to dense it to his daughter that is deflowred, and fo, by the A poftles iud o ement

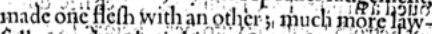
fully may hee denie his confent to her that is no maner of way boild, but is euery way fice $A$ ind if he haue power to deny his côfent in fuch a

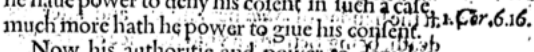

Now his authoritic and pow wi to den hits confent, is apparant by the expreffe comminu dement of God in that belaile, whis f faith $2 \sin 31$ Take beede to thy felfe, that thou mak nocit pact with' the inhabitants of the land's and' fó take Exod. 34

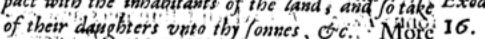

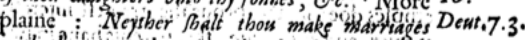
with tbern neither give thy daughtex whio bi fonne, nor take bis deiughter to thy fonne. Hoik could thoffe parents obferue this commatundement, vnleffe God had giuen them power to deny confent to their children? Or why dótli he I 4 rather

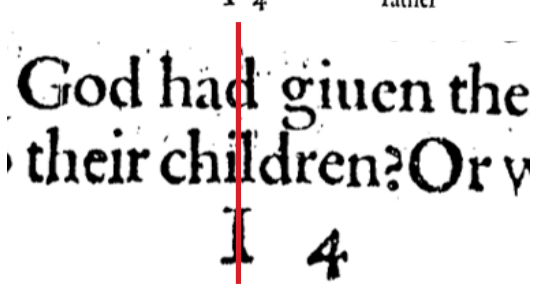

Figura 21 - Comparação do posicionamento da assinatura entre edições diferentes. A goldlie forme of hovseholde government (1598); A goldlie forme of hovseholde government (1600); A goldlie forme of hovseholde government (1 603). Exemplares digitalizados na Plataforma Early English Books Online. Imagens publicadas com permissão da ProQuest. Reprodução proibida.

Ao comparar a composição do texto entre as edições de 1600 e 1603, observam-se diferenças na margem direita da página, a que se somam divergências em apenas duas quebras de texto nas linhas nove e doze do bloco principal, além de poucas variantes ortográficas, como "sayth" e "saith" na linha 21 . A falta de padronização ortográfica das línguas europeias no período poderia ajudar o compositor a adequar o número de caracteres em uma linha. Entretanto, verificar pequenas diferenças gráficas e ortográficas entre edições é tarefa penosa, sobretudo no caso de contrafações mais cuidadosas. E o reconhecimento da reutilização de cadernos impressos em um momento posterior à tiragem da primeira edição é um dado importante para a pesquisa histórica sobre a produção, a comercialização e a circulação de impressos no período. Um caminho relativamente mais rápido e simples para identificação da edição pode ser a observação do alinhamento da assinatura com o texto principal. Uma vez que a disposição de espaços em branco na página para ordenar o posicionamento de um sinal gráfico destinado a organizar 
o trabalho de encadernadores e livreiros era algo que recebia menos atenção dos compositores do que a disposição gráfica na página do texto principal, frequentemente se identificam com mais facilidade nessa linha suplementar os deslizes deixados pelas mãos daqueles que manejavam os tipos móveis. Na imagem ampliada das linhas finais da mesma página das três edições, note-se a diferença no alinhamento da assinatura "I4" com as letras das palavras "had" e "children" impressas em linhas subsequentes. Essas variações nos convidam a investigar um aspecto fundamental do estudo de impressos à época da prensa manual. Considerando-se a variedade da produção de artefatos impressos no período, deve-se sempre procurar compreender não apenas o significado atribuído à informação textual e/ou visual registrada majoritariamente em papel, mas também considerar o que as características gráficas e materiais do objeto que se tem em mãos revelam. Trata-se da única e completa edição de uma obra impressa, de um exemplar incompleto, de estados distintos da mesma edição, de uma tiragem especial ou ainda de uma contrafação? Nem sempre a distinção é fácil, tanto do ponto de vista conceitual, quanto material.

Uma das definições mais recorrentes do conceito de edição nos estudos da bibliografia analítica é aquela feita por Fredson Bowes, segundo a qual "uma edição é o número inteiro de cópias de um livro impressas a qualquer momento [...] a partir de uma mesma composição tipográfica. "57 A unidade definidora da edição, portanto, é a composição tipográfica idêntica - ou seja, a mesma matriz de impressão -, de modo que os exemplares reproduzidos na figura 21 da obra A goldlie forme of hovseholde government... impressos em 1598, 1600 e 1603 indicam, de fato, a existência de três edições distintas. Ocorre que, em função dos custos de impressão relacionados, inclusive, ao preço do papel, erros presentes em um conjunto de cópias poderiam ser corrigidos ao longo das etapas de produção de uma obra. Nesse caso, tem-se estados distintos de um mesmo título que resultam de alterações feitas durante o processo de impressão. O termo é mais conhecido em língua portuguesa na descrição dos estados sucessivos da produção de gravuras. Analogamente, também para textos impressos fala-se de estados distintos quando se interrompe o trabalho da prensa para fazer correções nos tipos móveis após a leitura das folhas de prova, ou ainda quando o compositor é obrigado a reconstruir a matriz de impressão por conta de acidentes nas fôrmas ocorridos ao longo do processo de impressão. ${ }^{58}$ Por contenção econômica, evita-se com frequência o descarte de folhas já impressas, ainda que elas apresentem erros. De um ponto de vista prático, tem-se que os erros circulam, como é o caso do posicionamento incorreto da numeração de uma das páginas do Corpus Hippocraticum levado à prensa por Cratander em 1526. Todavia, nesse caso particular, o erro figura possivelmente em todos os exemplares, sendo, portanto, um elemento de identificação da edição. Já nas ocasiões em que
57. Bowes (2012, p. 39).

58. Ibid. (2012, p. 46-47). Adicionalmente, também se fala de estados distintos de uma edição quando há adição de material suplementar ou, contrariamente, nos casos em que um exemplar - ou mesmo toda uma edição - possa ter páginas canceladas ou suprimidas, com ou sem reposição de folha, em função, por exemplo, da ação da censura. Cf. Araújo (2014, p. 250). 
inadequações tipográficas eram percebidas e corrigidas, páginas integrantes de um mesmo título acabavam circulando em estados distintos.

Ocorre ainda que alterações voluntárias também podem ser feitas após o processo de impressão, resultando em uma configuração gráfica distinta do primeiro produto da prensa. Editores poderiam comercializar material encalhado como se fosse uma nova edição ao acrescentar aos cadernos estocados apenas uma nova folha de rosto e/ou novos cadernos introdutórios. Outra modificação intencional possível em um grupo particular de exemplares, feita de modo planejado por editores e impressores, poderia ser a impressão do livro em folhas de papel diferenciadas, obtendo-se agora como resultado uma tiragem especial da obra comercializada ou distribuída tanto em papel de melhor qualidade quanto em páginas de maiores dimensões e que proporcionam, consequentemente, margens mais amplas.

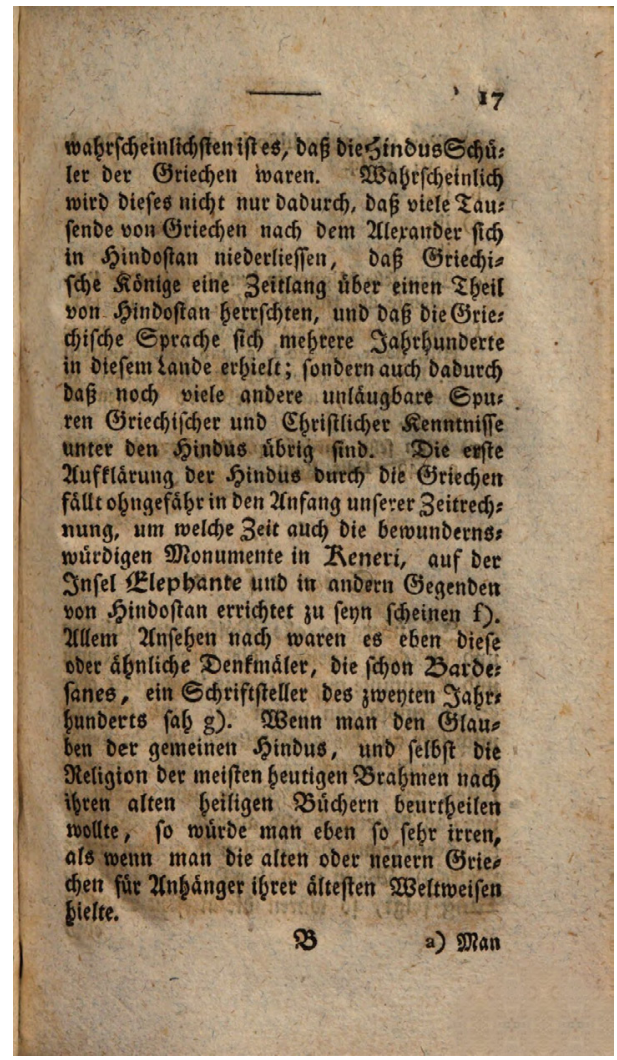

Figura 22 - Tiragens distintas de uma mesma edição. Meiners (1789, p. 17). Exemplares: Österreichische Nationalbibliothek (esq.) e Niedersächsische Staats- und Universitätsbibliothek Göttingen [n. cat.: 8 HLU III, 5585 (2)] (dir.).

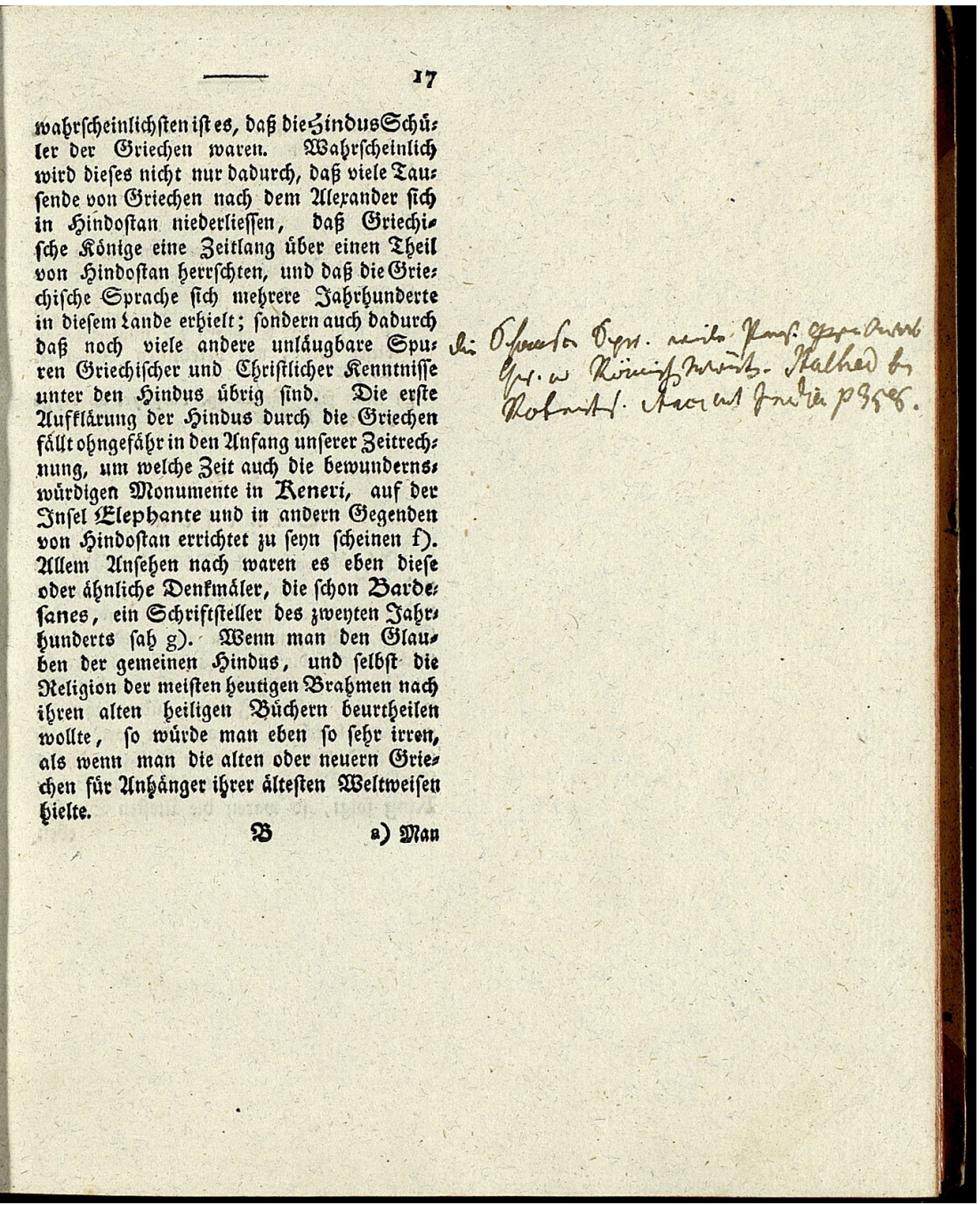


Uma vez que a Biblioteca Central da Universidade de Brasília não possui em seu acervo títulos que ilustrem tal variação dos produtos da prensa manual, apresentam-se aqui exemplares de duas outras coleções reproduzidos na Figura 22. Nela, encontram-se dispostas duas tiragens distintas da segunda edição da obra Grundriß der Geschichte der Weltweisheit, de Christoph Meiners, publicada em 1789. Note-se que o texto de todas as cópias remanescentes dessa edição encontrase delimitado pela mancha própria aos livros impressos in-octavo. No entanto, o impressor do exemplar preservado na biblioteca da Universidade de Göttingen organizou a produção de tal modo que o resultado final da página correspondesse à divisão da folha de papel própria às obras in-quarto. No caso deste exemplar em particular, as margens amplas favoreceram a anotação marginal registrada em tinta de base aquosa e feita com traços compatíveis com a caligrafia alemã do final do século XVIII. O texto manuscrito revela um rápido comentário de leitura e referência bibliográfica. Considerando-se o formato deste exemplar - identificado pelo número de vezes que a folha de papel foi dobrada para constituir os cadernos de texto -, a biblioteca da Universidade de Göttingen o catalogou corretamente como uma obra in-quarto. Todavia, o caso nos convida mais uma vez a observar tanto os padrões quanto as variações dos produtos da prensa, uma vez que seu registro catalográfico oblitera parcialmente as decisões tomadas por editores, impressores, livreiros e eventualmente leitores quanto à configuração final de tiragens especiais preparadas nas oficinas de impressão na Época Moderna. Assim, a análise comparativa das peças reproduzidas na Figura 22 nos remete ao ponto de partida deste artigo que nos fez observar as características gráficas e materiais de um título impresso in-folio no século XVI frente à sua descrição bibliográfica.

\section{O LIVRO E O EXEMPLAR}

Para identificar e compreender as alterações registradas na folha de rosto do exemplar preservado na Biblioteca Central da Universidade de Brasília do Corpus Hippocraticum publicado por Andreas Cratander em 1526, levou-se em consideração tanto as condições editoriais de produção do livro na Basileia durante a primeira metade do século XVI quanto as características gráficas e materiais da peça impressa. Neste caso particular, um erro na descrição bibliográfica da obra abriu espaço para que se investigasse paradigmaticamente a história de produção, consumo e preservação de artefatos impressos à época da prensa manual. No entanto, a origem 
59. Lacerda (2017, p. 2683).

60. Nava (2003, p. 47). das alterações presentes na folha de rosto do volume brasiliense - e que explicam o erro de catalogação da peça-ainda permanece marcada por dúvidas e certezas.

As informações registradas à mão no exemplar incorporado ao acervo da Universidade de Brasília em $1983^{59}$ e levado à prensa por Cratander em 1526 não se restringem às alterações feitas no campo em que se apresenta a data de publicação do título. Pequenas anotações de leitura distribuídas ao longo das páginas centrais somam-se às marcas de proveniência dispostas na folha de rosto. Esse é o caso do registro deixado de próprio punho pelo médico, escritor e bibliófilo brasileiro Pedro Nava no espaço localizado abaixo da imprenta e segundo o qual a obra foi adquirida na cidade de Paris, em 1961. Quase duas décadas depois, Nava informa que sua coleção hipocratiana contava com setenta volumes. "São quatrocentos e quarenta e três anos de médicos mortos, seus donos sucessivos até que esses livros chegassem até as minhas mãos" - nas palavras do bibliófilo -, "desde a edição de 1535 saída apenas dez anos depois da primeira veneziana em que se imprimiu o Pai da Medicina." 60

A edição datada de 1535 da Opera omnia de Hipócrates mencionada por Pedro Nava foi impressa in-octavo na cidade de Lyon. Seu exemplar particular encontrase atualmente preservado na Biblioteca Central da Universidade de Brasília e disposto próximo à cópia do Corpus Hippocraticum publicado na Basileia e adquirida pelo mesmo colecionador em 1961. Ocorre que, ao percorrer com os olhos os setenta volumes de sua coleção hipocratiana ao final da década de 1970, Pedro Nava não identifica a edição de Cratander como seu livro mais antigo. Nesse momento, é muito provável que a informação referente à data de publicação registrada com tipos móveis no papel deste exemplar já se encontrasse alterada pela pena. Certo, todavia, é que os registros de proveniência da peça adquirida em Paris - e em função dos quais se poderia levantar hipóteses quanto à origem da alteração verificada - são lacunosos.

Dentre as marcas deixadas pelos "donos sucessivos" do exemplar até que ele chegasse às mãos do colecionador brasileiro, identifica-se apenas a inscrição "Ex Libris J Laurentij", localizada na porção superior da folha de rosto, ou seja, do dispositivo gráfico por meio do qual editores e impressores apresentavam os produtos da prensa. Trata-se de inscrição feita com material e forma caligráfica compatíveis com os registros manuscritos da época moderna, mas com tinta distinta daquela utilizada para alterar as informações da imprenta. Assim, não se pode fazer inferências seguras relativas à introdução manual de novos números romanos na folha de rosto do Corpus Hippocraticum editado por Cratander em 1526, de modo a nela fazer figurar o ano de 1538. Contudo, o argumento que se defende neste artigo é que o exemplar que passou por distintas mãos antes de ser integrado ao acervo da Universidade de Brasília pode ser explorado pela pesquisa histórica não apenas a 
partir de uma perspectiva de trabalho que se atenha exclusivamente à informação textual ou à trajetória dos volumes. Ao explorar aspectos relacionados à forma e à materialidade de artefatos impressos na Época Moderna, vimos que os produtos da prensa manual também podem fornecer evidências gráficas e materiais que apontam para a existência de colaborações ${ }^{6 l}$ e conflitos travados entre diversas oficinas na disputa por espaço na produção e na venda de títulos, dentre os quais o Corpus Hippocraticum publicado em 1526 figura paradigmaticamente como exemplo.

Na década em que Cratander leva esses tratados médicos associados ao nome de Hipócrates à prensa, o trabalho empreendido nas oficinas de impressão da Basileia se encontrava fora do sistema de guildas ou corporações de ofício. Entretanto, com o objetivo de defender interesses de ordem predominantemente econômica, diversos impressores se associaram às guildas dos comerciantes principalmente àquelas denominadas Safran e Schlüssel -, 62 uma vez que também realizavam a venda de seus produtos. Da proximidade física e comercial entre aqueles que se ocupavam da produção de impressos na Basileia nesse período resulta uma série padrões gráficos estabelecidos coletivamente e que se observam nas obras de diversas oficinas. Esse é o caso de folhas de rosto impressas por Valentin Curio e Cratander, como visto na introdução deste artigo, na qual também se apresenta o surgimento de um conflito travado judicialmente entre os mesmos impressores por conta da publicação de um dicionário da língua grega. Tal disputa levou à criação do Estatuto dos Impressores da Basileia, em 1531. Segundo esse instrumento jurídico, as oficinas de impressão locais não poderiam, no espaço de três anos, produzir nova edição de um título já impresso. Adicionalmente, nenhum impressor poderia, doravante, tentar persuadir corretores, compositores, operadores da prensa ou quaisquer outros trabalhadores em uma determinada oficina a deixarem-na para trabalhar para si. ${ }^{63}$ Nesses termos, o estatuto fornece evidência documental segura relativa à grande mobilidade que caracterizava o trabalho daqueles que se dedicavam ao ofício da impressão na Basileia ao longo das primeiras décadas do século XVI. Mas eis que o resultado gráfico de tal mobilidade se verifica igualmente nos modos de organização textual e visual da informação registrada em papel, como apresentado neste artigo. Assim, evidencia-se o ganho analítico que o estudo da materialidade de impressos no período da prensa manual, de sua produção gráfica coletiva e de seus processos de edição, bem como dos modos de organização textual e visual da informação registrada em papel ao longo do tempo trazem para a pesquisa histórica. Vistos a partir desta perspectiva, os artefatos impressos na Época Moderna não são apenas veículos de mensagens predominantemente textuais, mas também vestígios materiais de relações sociais de produção, circulação, consumo e preservação da informação.
61. Sobre as colaborações estabelecidas ao longo do século XVI entre diversos impressores da Basileia, cf. Leu (2014, sobretudo p. 59).

62. Benzing (1963, p. 32).

63. Erkanntnisbuch (1531, f. 96r). 


\title{
REFERÊNCIAS
}

\author{
FONTE MANUSCRITA
}

Erkanntnisbuch, Ratsbücher B 4, Basel: 1531, Staatsarchiv Basel-Stadt. Disponível em: <www. copyrighthistory.org>. Acesso em: 22 mar. 2021.

FONTES IMPRESSAS

A goldlie forme of hovseholde government... Gathered by R. C. At London. Printed by Felix Kingston, for Thomas Man, 1598.

A goldlie forme of hovseholde government... Gathered by R. C. At London. Printed by Felix Kingston, for Thomas Man, 1600.

A goldlie forme of hovseholde government... Gathered by R. C. At London. Printed by Thomas Creede, for Thomas Man, 1603.

Bibliotheca Colbertina: seu Catalogus librorum bibliothecae... Pars secunda. Parisiis: Apud Gabrielem Martin; Fransciscum Montalant, 1728.

Commentariorvm lingvae latinae tomvs secvndvs. Lvgdvni: Seb. Gryphivm, 1538.

Dialogos de Dom Frey Amador Arraiz... Coimbra: Diogo Gomez Lovreyro, 1604.

Divi Clementis Recognitionvm Libri X... Basileae: Johann Bebel, 1526.

Galeni Pergameni Svummi Semper Viri... Basileae: Cratander, 1538.

GESSNER, Christian Friedrich. Der in der Buchdruckerei wohlunterrichtete Lebr-Junge... Leipzig: Geßner, 1743.

Hippocratis coi medicorvm omnivm... Basileae: Cratander, 1526.

Lexicon iuris sev epitome definitionum, \& rerum... Lvgdvni, 1549.

MATTIAE, Christian. Theatrvm Historicvm Theoretico-Practicvm... Amstelodami: Ludovicum Elzevirium, 1648. 
MEINERS, Christoph. Grundriß der Geschichte der Weltweisheit. Zweyte verbesserte Auflage. Lemgo: Meyer, 1789.

MOXON, Joseph. Mechanick Exercises: Or, the Doctrine of handy-works. Applied to the Art of Printing. London: Printed for Joseph Moxon, 1683.

PIAMONTES, Alexo. Secretos del Reverendo Don Alexo Piamontes. Madrid: Jvan Garcia: 1691.

PISO, Willem. Historia Natvralis Brasiliae... Lvgdvn. Batavorvm; Amstelodami: Franciscum Hackium; Lud. Elzevirium, 1648.

PLAT, Hugh. The Jewell House of Art and Nature. London: Peter Short, 1594.

PLÍNIO CECÍlIO SEGUNDO, Caio. Epistolarvm Lib. X. Veneunt Iodoco Badio \& Ioanni Roigny, 1533.

[PORTUGAL, D. Francisco de]. Divinos, e hvmanos versos... Lisboa: Officina Craesbeckiana, 1652.

REINESIUS, Thomas. Syntagma inscriptionum antiquarum... Lipsiae; Francofurti: Haered; Gleditisch; Hahnius, 1682.

UZ, J. P. Sämmtliche poetische Werke. Carlsruhe: Christian Gottblieb Schmieder, 1776.

Valentinvs cvrio lectori... Basileae: Valentino Curio, 1523.

ZIMMERMANN, Matthias. Analecta Miscella Menstrua Eruditionis Sacrae E Profanae Theologicae, Liturgicae, Historicae, Philologicae, Moralis, Symbolicae, Ritualis, Curiosae... Misenae: Güntherus, 1674.

LIVROS, ARTIGOS E TESES

ALMADA, Márcia. A mão, o olho e a matéria: reflexões sobre a identificação das técnicas e materiais da pintura em documentos históricos. Anais do Museu Paulista, São Paulo, v. 26, p. 1-30, 2018. DOI: 10.1590/1982-02672018v26e02d1. Disponível em: <https://bit.ly/31FSFoB >. Acesso em: 22 mar. 2021.

ALMADA, Márcia; MONTEIRO, Rodrigo Bentes. O Discurso e a Noticia: manuscritos sobre a revolta de 1720 atribuídos a Pedro Miguel de Almeida, $3^{\circ}$ conde de Assumar. Tempo, Niterói, v. 25 , n. 1 , p. 1-25, 2019. 
ARAÚJO, André de Melo. Tradução Ilustrada: Imagens da História Universal inglesa e de suas edições europeias no século XVIII. História da Historiografia, Mariana, n. 26, p. 69-100, 2018.

ARAÚJO, André de Melo. O conhecimento impresso: práticas editoriais e estratégias comerciais nos manuais de impressão da Época Moderna. Varia Historia, Belo Horizonte, v. 36, n. 70, p. 53-90, 2020a.

ARAÚJO, André de Melo. A primeira página da história: configuração material e funções da folha de rosto em livros de história alemães do século XVIII. Anais do Museu Paulista, São Paulo, v. 28, p. 1-37, 2020b. DOI: 10.1590/1982-02672020v28d3e34. Disponível em: <https:// bit.ly/3scxQUf>. Acesso em: 22 mar. 2021.

ARAÚJO, Emanuel. A construção do livro: princípios da técnica de editoração. 2. ed. Rio de Janeiro: Lexikon, 2014.

AZEVEDO, Fabiano Cataldo de. A new project for provenance research in Brazil. The Library, Oxford, v. 21, n. 1, p. 112, 2020.

AZEVEDO, Pedro de. O primeiro livro impresso no Brasil: censo e validação dos exemplares conhecidos: a case study. In: ANDRADE, António Manuel Lopes; CARRINGTON, Maria Cristina (eds.). Do manuscrito ao livro impresso I. Coimbra: Universidade de Coimbra: Imprensa da Universidade de Coimbra, 2019. p. 91-135.

BARROS, Jerônimo Duque Estrada de. Impressões de um tempo: a tipografia de Antônio Isidoro da Fonseca no Rio de Janeiro (1747-1750). 2012. Dissertação (Mestrado em História) Universidade Federal Fluminense, Niterói, 2012.

BENZING, Joseph. Die Buchdrucker des 16. und 17. Jabrhunderts im deutschen Sprachgebiet. Wiesbaden: Otto Harrassowitz, 1963.

BIDWELL, John. French paper in English books. In: BARNARD, John; MCKENZIE, D. F. (eds.). The Cambridge History of the Book in Britain, volume IV: 1557-1695. Cambridge: Cambridge University Press, 2002. p. 583-601.

BIDWELL, John. The industrialization of the paper trade. In: SUAREZ, Michael F.; TURNER. Michael L. (eds.). The Cambridge history of the book in Britain, volume V: 1695-1830. Cambridge: Cambridge University Press, 2009. p. 200-217.

BIETENHOLZ, Peter G. Andreas Cratander. In: BIETENHOLZ, Peter G.; DEUTSCHER, Thomas B. (eds.). Contemporaries of Erasmus: a biographical register of the Renaissance and Reformation. Toronto: University of Toronto Press, 1985. p. 357-358.

BOWES, Fredson. Principles of bibliographical description. New Castle: Oak Knoll Press, 2012. 
CHAMBERLAIN, Daven Christopher. Paper. In: SUAREZ, Michael; WOUDHUYSEN, Henry R. (eds.). The book: a global history. Oxford: Oxford University Press, 2013. p. 116-129.

DAVIES, Martin. Humanist in script and print in the Fifteenth Century. In: KRAYE, Jill (ed.). The Cambridge Companion to Renaissance Humanism. Cambridge: Cambridge University Press, 1996. p. 47-62.

DODGSON, Campbell. The engravers on metal after Holbein. The Burlington Magazine for Connoisseurs, London, v. 83, n. 488, p. 282-285, 1943.

FARIA, Maria Isabel; PERICÃO, Maria da Graça. Dicionário do livro: da escrita ao livro eletrônico. São Paulo: Edusp, 2008.

FARIAS, Priscila L. Estudos sobre tipografia: letras, memória gráfica e paisagens tipográficas. 2016. Tese (Livre-docência em Arquitetura e Urbanismo) - Universidade de São Paulo, São Paulo, 2016.

FEBVRE, Lucien; MARTIN, Henri-Jean. O aparecimento do livro. São Paulo: Edusp, 2017.

FOOT, Mirjam M. Bookbinding. In: BARNARD, John; McKENZIE, D. F. (eds.). The Cambridge bistory of the book in Britain, volume IV: 1557-1695. Cambridge: Cambridge University Press, 2002. p. 620-631.

FUCHS, Barbara; PALMER, Philip S. A Lettered Utopia: Printed Alphabets and the Material Republic of Letters, Renaissance Quarterly, Cambridge, v. 73, n. 4, p. 1235-1276, 2020.

GARONE GRAVIER, Marina. A tipografia da oficina plantiniana: impacto e transcendência nas tipografias hispano-americanas. In: THOMAS, Werner; STOLS, Eddy; KANTOR, Íris; FURTADO, Júnia (orgs.). Um mundo sobre papel: livros, gravuras e impressos flamengos nos impérios português e espanhol (séculos XVI-XVIII). São Paulo: Edusp; Belo Horizonte: Editora UFMG, 2014. p. $125-147$.

GARONE GRAVIER, Marina. Cultura impresa colonial en lenguas indígenas: una visión histórica y regional. Ensayos, [s. l.], n. 18, p. 98-145, 2010.

GASKELL, Philip. A new introduction to bibliography. New Castle: Oak Knoll Press, 2012.

GREENHALGH, Raphael Diego. Segurança contra roubo e furto de livros raros: uma perspectiva sob a ótica da economia do crime e da teoria da dissuasão. 2014. Tese (Doutorado em Ciência da Informação) - Universidade de Brasília, Brasília, DF, 2014.

HEDGES, S. Blair. A method for dating early books and prints using image analysis. Proceedings of the Royal Society A., Londres, v. 462, p. 3555-3573, 2006. 
HENTSCHELL, Roze. The culture of cloth in Early Modern England: textual constructions of a national identity. Aldershot: Routledge, 2008.

JOUANNA, Jacques. Textual history. In: PORMANN, Peter E. (ed.). The Cambridge Companion to Hippocrates. Cambridge: Cambridge University Press, 2018. p. 38-62.

KUSUKAWA, Sachiko. Picturing the book of nature: image, text, and argument in sixteenthcentury human anatomy and medical botany. Chicago: The University of Chicago Press, 2012.

LACERDA, Ana Regina Luz. A importância das bibliotecas particulares incorporadas aos acervos públicos: As coleções da Biblioteca Central da Universidade de Brasília. Revista Brasileira de Biblioteconomia e Documentação, São Paulo, v. 13, n. esp. CBBD 2017, p. 2673-2689, 2017.

LOSE, Alícia Duhá; MAZZONI, Vanilda Salignac. O patrimônio documental baiano: descrição material de documentos do século 19. Herança, [s. l.], v. 3, n. 1, p. 124-144, 2020.

LEU, Urs B. Die Bedeutung Basels als Druckort im 16. Jahrhundert. In: CHRIST-VON WEDEL, Christine; GROSSE, Sven; HAMM, Berndt (eds.). Basel als Zentrum des geistigen Austauschs in der früben Reformationszeit. Tübingen: Mohr Siebeck, 2014. p. 53-78.

MEULEN, David L. Vander. The identification of paper without watermarks: the example of Pope's 'Dunciad'. Studies in Bibliography, Charlottesville, v. 37, p. 58-81, 1984.

NAVA, Pedro. Galo-das-trevas: (as doze velas imperfeitas). São Paulo: Ateliê Editorial, 2003.

NEEDHAM, Paul. Format and paper size in fifteenth-century printing. In: RESKE, Christoph; SCHMITZ, Wolfgang (eds.). Materielle Aspekte in der Inkunabelforschung. Wiesbaden: Harrassowitz, 2017. p. 59-107.

PEARSON, David. Provenance research in book history: a handbook. Oxford: Bodleian Library, 2019.

PEARSON, David. Bookbinding history and sacred cows. The Library, [s. l.], v. 21, n. 4, p. 498$517,2020$.

PETTEGREE, Andrew. The book in the Renaissance. New Haven: Yale University Press, 2011.

PICKWOAD, Nicholas. Bookbinding in the Eighteenth Century. In: SUAREZ, Michael F.; TURNER. Michael L. (eds.). The Cambridge bistory of the book in Britain, volume V: 1695-1830. Cambridge: Cambridge University Press, 2009. p. 268-290.

RAVEN, James (ed.). The Oxford illustrated bistory of the book. Oxford: Oxford University Press, 2020. 
ROBINSON, Pamela. Materials: paper and type. In: GILLESPIE, Vincent; POWELL, Susan (eds.). A companion to the early printed book in Britain, 1476-1558. Cambridge: Brewer, 2014. p. 61-74.

SAWYER, Daniel. Page numbers, signatures, and catchwords. In: DUNCAN, Dennis; SMYTH, Adam (eds.). Book parts. Oxford: Oxford University Press, 2019.

SCHMID, Heinrich Alfred. Holbeins Thätigkeit für die Baseler Verleger. Jabrbuch der Königlich Preussischen Kunstsammlungen, [s. l.], v. 20, p. 233-262, 1899.

SEBASTIANI, Valentina. Johann Froben, printer of Basel: a biographical profile and catalogue of his editions. Leiden: Brill, 2018.

SIRAISI, Nancy G. History, medicine, and the traditions of Renaissance learning. Ann Arbor: The University of Michigan Press, 2007.

STEVENSON, Allan. Paper as bibliographical evidence. The Library, [s. l.], v. 17, n. 3, p. $197-$ $212,1962$.

VERVLIET, Hendrik D. L. The palaeotypography of the French Renaissance: selected papers on sixteenth-century typefaces, volume 1. Leiden: Brill, 2008.

WINGER, Howard W. The cover design. The Library Quarterly: Information, Community, Policy, Chicago, v. 53, n. 4, p. 456-457, 1983.

WITT, Mathias. Fabio Calvo: Übersetzer, Herausgeber und Fälscher hippokratischer Schriften. Sudhoffs Archiv, [s. l.], v. 102, n. 1, p. 33-88, 2018.

Artigo apresentado em: 22/11/2020. Aprovado em: 02/03/2021.

\section{(cc) BY}

